\title{
ANALYSIS OF ELECTRICITY INDUSTRY LIBERALIZATION IN GREAT BRITAIN: HOW DID THE BIDDING BEHAVIOR \\ OF ELECTRICITY PRODUCERS CHANGE?
}

Sherzod N. Tashpulatov
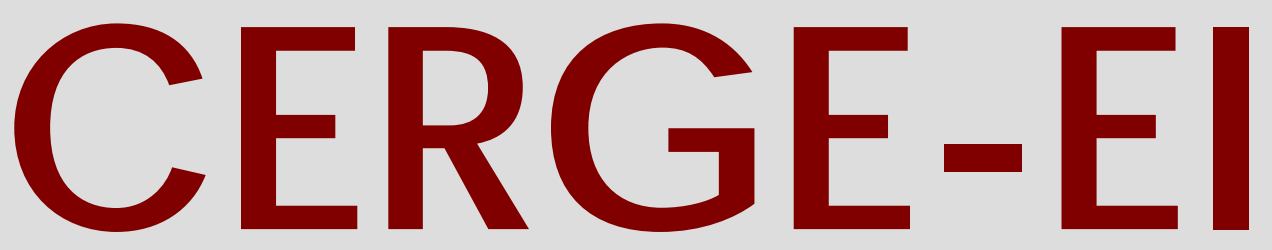

Charles University Centerfor Ec onomic Research and Graduate Education Academy of Sciences of the Czech Republic Ec onomic s Institute 


\title{
Working Paper Series (ISSN 1211-3298)
}

\section{Analysis of Electricity Industry Liberalization in Great Britain: How Did the Bidding Behavior of Electricity Producers Change?}

Sherzod N. Tashpulatov

\author{
CERGE-EI \\ Prague, September 2010
}
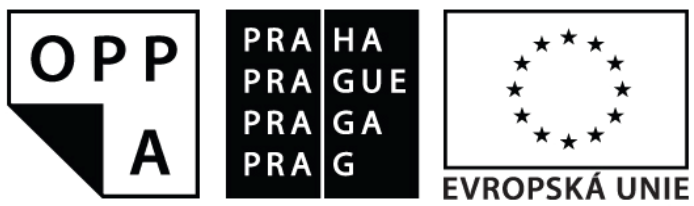

EVROPSKÝ SOCIÁLNÍ FOND

PRAHA \& EU: INVESTUJEME DO VAŠÍ BUDOUCNOSTI

Projekt je financován Evropským sociálním fondem, rozpočtem hl. města Prahy a státním rozpočtem 
ISBN 978-80-7343-213-3 (Univerzita Karlova. Centrum pro ekonomický výzkum a doktorské studium)

ISBN 978-80-7344-203-3 (Národohospodářský ústav AV ČR, v.v.i.) 


\title{
Analysis of Electricity Industry Liberalization in Great Britain: How Did the Bidding Behavior of Electricity Producers Change?
}

\author{
Sherzod N. Tashpulatov*
}

\author{
CERGE-EI ${ }^{\dagger}$
}

WP 415 (updated)

\begin{abstract}
Promoting competition among electricity producers is crucial for ensuring allocative efficiency and lower electricity prices. In this paper, I empirically examine the electricity market of England and Wales in order to analyze to what extent the regulatory reforms were successful at promoting competition among electricity producers during 1995-2000.

This research provides further evidence of the effects of the reforms undertaken by the regulatory authority during the liberalization process and could be also of interest to countries that created their wholesale electricity markets similar to the original model of the England and Wales wholesale electricity market.
\end{abstract}

\begin{abstract}
Abstrakt
Prosazování konkurence mezi výrobci elektřiny je důležité, nebot' ve svém důsledku zajišt'uje alokační efektivnost a nižší ceny elektřiny. V tomto článku empiricky zkoumám trh elektřiny v Anglii a Walesu, kde analyzuji úspěšnost regulačních reforem při zavádění konkurence mezi výrobci elektřiny během let 1995-2000.

Tento výzkum poskytuje další informace o efektivitě reforem, které regulační orgán provedl $\mathrm{v}$ průběhu liberalizace a je proto také vhodným informačním podkladem pro země, které reformovaly své velkoobchodní trhy elektřiny podobně jako tomu bylo $\mathrm{v}$ př́padě velkoobchodního trhu elektřiny v Anglii a Walesu.
\end{abstract}

Keywords: liberalization, electricity markets, uniform price auction, market power, regulation

JEL Classification: D21, D44, L90, L94

*I would like to express my gratitude to Lubomír Lízal, Jan Hanousek, and Jan Kmenta for invaluable comments, suggestions, and guidance. I am thankful to Fabio Michelucci and Peter Katuščák for comments on the earlier drafts. I am also thankful to Richard Stock and Sarah Peck for their help and advice on English language. All remaining errors are mine. This paper was supported by the World Bank Research Fellowship grant and SVV-2010-261 801 grant.

${ }^{\dagger}$ A joint workplace of the Center for Economic Research and Graduate Education, Charles University, and the Economics Institute of the Academy of Sciences of the Czech Republic

Address: CERGE-EI, P.O. Box 882, Politickych veznu 7, Prague 111 21, Czech Republic

E-mail: stashpul@cerge-ei.cz 


\section{General Introduction}

Network industries like energy (for example, electricity and natural gas), postal services, telecommunications, and transport (for example, air, maritime, and rail) provide essential services of general economic interest. Promotion of competition at all possible levels of these network industries was the primary goal of the liberalization process started during the 1990s in many European countries (Bergman et al., 1998).

In general, a network industry is an industry in which products are provided to customers via a network infrastructure. As described in Bergman et al. (1998), a network industry is represented by three key components: core products, network infrastructure, and customer service provision. These are schematically presented in Figure 1.1.

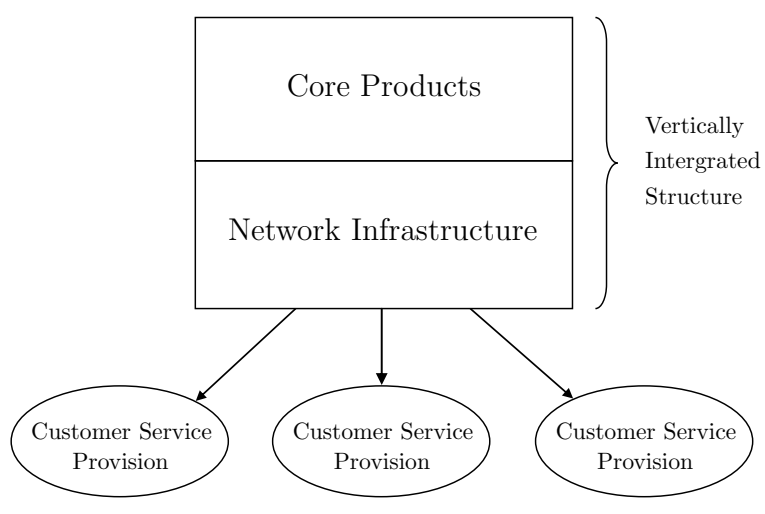

(a) Vertically Integrated Case

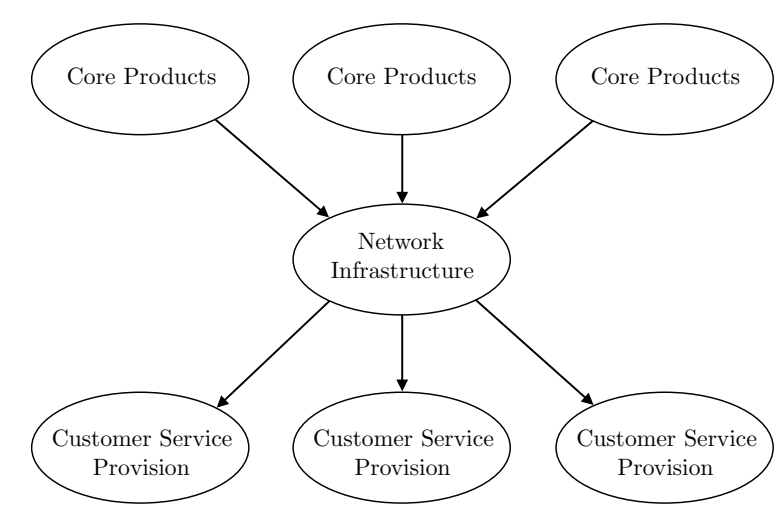

(b) Vertically Separated Case

Source: Bergman et al. (1998).

Figure 1.1: Structure of a Network Industry

Core products are delivered by producers in the upstream production level and customer service provision is delivered by suppliers in the downstream supply level. The upstream production and downstream supply levels are coordinated via the network infrastructure.

Until the 1980s the upstream production and network infrastructure levels were mostly vertically integrated and regulated as a single "natural monopoly" structure, which is described in Figure 1.1(a). It was then widely believed that those vertically integrated organizations are better managed as regulated state or private natural monopolies, mainly due to the presence of economies of scale and large fixed costs (Geradin, 2006).

The liberalization in network industries included splitting the previously vertically integrated monopoly structure, which is described in Figure 1.1(b). The purpose of 
this restructuring was to introduce competition in the upstream production and downstream supply levels while still allowing for the network infrastructure to remain the only monopoly structure because its replication is not economical.

In the case of an electricity industry, for example, the upstream production level is represented by electricity producers, the network infrastructure by the network operator responsible for electricity transmission over a high-voltage net, and the downstream supply level by retail suppliers responsible for electricity distribution over a low-voltage net.

In Great Britain, following the lessons learnt from privatizing the gas industry in 1986, the Chairman of the Central Electricity Generation Board (CEGB) and government consultants demonstrated that splitting the vertically integrated CEGB into production and network infrastructure parts was feasible. The purpose of splitting the vertically integrated utility was to introduce competition in the production level while still allowing for the network infrastructure to remain the only natural monopoly segment. In this respect, Great Britain was the first among the OECD countries to liberalize its Electricity Supply Industry (ESI), where the liberalization therefore included the vertical separation of electricity production and network infrastructure parts, which were previously integrated in the CEGB. At the same time, in the distribution level, the Regional Electricity Boards were replaced by 12 Regional Electricity Companies (RECs). These changes were then immediately followed by the creation of a wholesale electricity market in England and Wales, which operated during April 1, 1990 - March 26, 2001.

Competition in the production and distribution levels of the ESI in Great Britain was aimed at promoting a decrease of electricity prices for customers and hence, consequently, also an increase in total wealth. However, since the competition among producers and among retail suppliers was introduced gradually, there was an opportunity for electricity producers and retail suppliers to earn high profits. The noncompetitive behavior of producers through an exercise of market power and of retail suppliers through monopoly franchises were facilitating the transfer of the resulting high electricity prices to consumers, who during the 1990s were not allowed to completely freely switch among retail suppliers.

Besides resulting in high wholesale electricity prices, the noncompetitive behavior of electricity producers may also create allocative and productive inefficiencies. On the one hand, if the exercise of market power is present, then the bidding behavior of producers need no longer reflect their costs. This may therefore create allocative inefficiency: a less expensive producer may stop serving the demand because it is replaced by a more 
expensive producer in the wholesale electricity market, if the former desired a significantly higher price markup. On the other hand, in a less competitive environment producers might not be sufficiently motivated to improve productive efficiency, that is, to drive out high-cost production capacity.

In order to increase competition among electricity producers, several reforms were introduced by the regulatory authority. In this research, I empirically evaluate the influence of the regulatory reforms during the liberalization process of the ESI on the development of competition among electricity producers. The findings and conclusions of this research document new evidence about the liberalization process of the electricity industry in Great Britain, which could be also of interest to, for example, Argentina, Australia, Chile, Italy, Spain, and some US states that have adopted trading arrangements similar to those of the wholesale electricity market in England and Wales.

Paul Joskow characterized the privatization, restructuring, market design, and regulatory reforms pursued in the liberalization process of the electricity industry in England and Wales as the international gold standard for energy market liberalization (Joskow, 2009). In this respect, Great Britain, with the longest liberalization experience, can also serve as an important source of lessons.

In the following two sections, I present the institutional description of the electricity industry and the research on the development of the bidding behavior of electricity producers in relation to the regulatory reforms introduced during the liberalization process of the electricity industry in Great Britain. 


\section{Background Electricity Supply Industry in Great Britain}

\subsection{Liberalization of Electricity Supply Industry}

According to evaluations provided in Bergman et al. (1998), the liberalization of the Electricity Supply Industry (ESI), which included the opening of the market for competitors, the creation of a level playing field, and measures designed to promote competition, was more extensive in Great Britain compared to Germany, Italy, Spain, or Sweden.

The liberalization of the ESI in Great Britain, started in 1990, included splitting the vertically integrated utility into production and network infrastructure parts and at the same time the creation of the wholesale electricity market in England and Wales. It is worth mentioning that electricity exchange in the created wholesale electricity market constituted more than $85 \%$ of the total electricity exchange in Great Britain (see, for example, Department of Trade and Industry, 1997-2002; Newbery, 1999).

The ESI as any other network industry encompassed three levels: production represented by electricity producers, network infrastructure represented by a network operator, and distribution represented by electricity suppliers. Figure 2.1 presents in detail these levels of the ESI for the case of Great Britain.

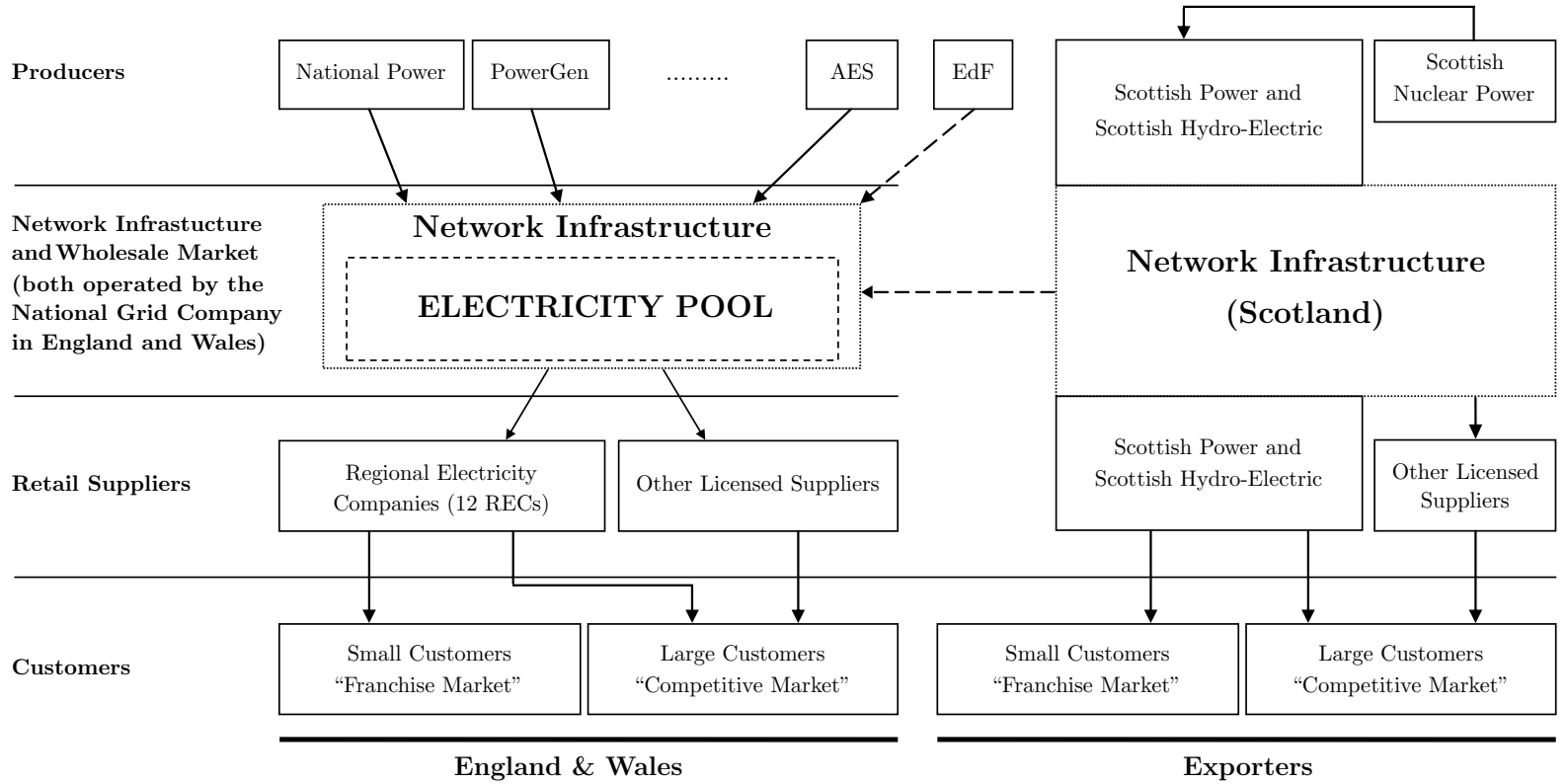

Source: Department of Trade and Industry (1997-2002). Modified for illustration purposes.

Figure 2.1: Description of the Electricity Supply Industry in Great Britain in 1998 
As described in Figure 2.1, in England and Wales, electricity producers sell electricity to retail suppliers through the wholesale market known as the Electricity Pool, which was managed by the network operator, the National Grid Company (NGC). The NGC was also responsible for transmitting electricity to retail suppliers over a high-voltage net. Finally, retail suppliers distribute electricity to final customers over a low-voltage net.

In Scotland, the South of Scotland Electricity Board and the North of Scotland HydroElectric Board were replaced by Scottish Power and Scottish Hydro-Electric, which are responsible for production, transmission, and retail supply. As illustrated in Figure 2.1, the production and transmission have been kept vertically integrated and were not unbundled as was done, for example, in England and Wales.

The liberalization process of the ESI during the 1990s included several institutional changes and regulatory reforms. Those changes and reforms both in the production and distribution levels shared heavy-handed features of regulation, because specific rules and institutions were established to regulate the ESI in Great Britain. The institutional changes and regulatory reforms that took place in the production level of the ESI in Great Britain during 1990-2001 are summarized in Figure 2.2.

\begin{tabular}{|c|c|c|c|c|c|c|}
\hline $\begin{array}{l}\text { Creation of } \\
\text { Wholesale } \\
\text { Electricity } \\
\text { Market }\end{array}$ & $\begin{array}{l}\text { End of Coal } \\
\text { Contracts }\end{array}$ & $\begin{array}{l}\text { Start of } \\
\text { Price-Cap } \\
\text { Regulation }\end{array}$ & $\begin{array}{l}\text { End of } \\
\text { Price-Cap }\end{array}$ & Divestment 1 & Divestment 2 & $\begin{array}{l}\text { Restructure of } \\
\text { Wholesale } \\
\text { Electricity } \\
\text { Market }\end{array}$ \\
\hline Regime 1 & Regim & Regime & Pre-1 & ne 4 & & \\
\hline
\end{tabular}

Sources: Department of Trade and Industry (1997-2002), National Grid Company (1994-2001), Newbery (1999), Robinson and Baniak (2002), Wolfram (1999); author's illustration.

\section{Figure 2.2: Institutional Changes and Regulatory Reforms during 1990-2001}

In the following paragraphs I describe the structural breaks and regimes, summarized in Figure 2.2. The Director General of Electricity Supply (DGES), Stephen Littlechild, noted the growing discrepancy between rising wholesale electricity prices and falling fuel costs, and specifically the sharp increase in electricity prices in April 1993. In the literature, this is also associated with the expiry of coal and other initial contracts imposed by the government. Hence, April 1, 1993 is considered as the first structural break.

The DGES concluded that an exercise of market power had enabled electricity producers to raise prices above competitive levels. For this reason, the DGES advocated the introduction of price-cap regulation into the ESI, which would set an explicit ceiling on annual average prices charged for electricity production by the two incumbent electricity producers: National Power (the larger producer) and PowerGen (the smaller 
producer). Faced with the alternative of a referral to the Monopolies and Mergers Commission (MMC), ${ }^{1}$ these electricity producers agreed to a price cap for two financial years: 1994/1995 and 1995/1996 (Wolfram, 1999; Robinson and Baniak, 2002). Therefore, April 1, 1994 and April 1, 1996 are considered as the second and third structural breaks, respectively.

The price-cap regulation was a temporary measure until the regulatory authority, the Office of Electricity Regulation (OFFER), found an acceptable approach to discipline the bidding behavior of electricity producers in order to ensure the allocative efficiency of production resources and lower electricity prices. Horizontal restructuring through the forced divestment of production capacity was the approach that the OFFER applied to gradually increase competition and mitigate the exercise of market power in the England and Wales electricity market. Under regulatory pressure, the two incumbent electricity producers, National Power and PowerGen, divested (more precisely, leased instead of a planned sale) 6,000 MW of production capacity to Eastern Group (later renamed TXU). In particular, on June 26, 1996, National Power divested the Ironbridge, Rugeley, and West Burton plants, which in total represented 4,000 MW of its 26,000 MW production capacity. Similarly, on July 1, 1996, PowerGen divested the Drakelow and High Marnham plants, which in total represented 2,000 MW of its 20,000 MW production capacity (National Grid Company, 1994-2001). Therefore, I consider April 1, 1996 - June 22, 1996 as an inactive period and July 1, 1996 as the fourth structural break. ${ }^{2}$

Eastern Group, one of the largest Regional Electricity Companies (RECs), thereby also became a major electricity producer. As part of the lease, Eastern paid National Power and PowerGen £6/MWh of electricity produced, increasing accordingly Eastern's marginal costs. This arrangement with PowerGen was terminated in March 2000 while the payment to National Power was reduced to £1.5/MWh in summer 2000 and came to an end in January 2001 when Eastern bought the plants from National Power (Bower, 2002). These changes are appropriately accounted for in the approximation of

\footnotetext{
${ }^{1}$ The MMC was later renamed the Competition Commission (CC).

${ }^{2}$ For an ex-post regulation analysis, I consider the exact dates when the divestments took place. This approach better corresponds to the nature of the divestment series introduced by the regulatory authority. For example, the introduction of the first series of divestments for PowerGen led to the transfer of all medium coal production facilities to Eastern Group (National Grid Company, 1994-2001). A separate analysis of the bidding behavior of PowerGen with respect to medium coal production facilities several days or weeks before the actual divestment took place may not be statistically reliable due to a small number of observations. For Eastern Group, it would not be possible because Eastern Group did not have coal production facilities before. Therefore, I assume that the structural breaks are exogenously given by the dates when the reforms were introduced.
} 
the marginal costs of the divested plants.

The most serious criticism of the performance of the electricity market was the continuing influence of National Power and PowerGen on setting the uniform auction price and the further need for the divestment of production capacity in 1999, despite the earlier divestment of 6,000 MW of production capacity and the increased entry by Independent Power Producers (IPPs). After negotiations and gaining permission to merge with a Regional Electricity Company (REC), PowerGen sold the Ferrybridge (1,956 MW) and Fiddlers Ferry (1,960 MW) plants to Edison and, similarly, National Power sold the Drax plant (3,870 MW) to AES in July 1999. Therefore, I consider July 1999 as the fifth structural break.

The ultimate goal of the regulatory reforms introduced by the OFFER in the production level was to ensure that prices were set such that markups over marginal costs were sufficient to cover fixed and other common costs. This was crucial because otherwise the exercise of market power expressed in submitting price bids significantly higher than marginal costs could lead to an inefficient allocation of production resources since, as described in Section 2.2, a supply schedule constructed based on price bids need no longer guarantee that the least-cost production units are indeed scheduled to produce electricity. This would eventually result in higher prices paid by consumers.

On March 27, 2001, the Electricity Pool was replaced by the New Electricity Trading Arrangements (NETA). The new trading arrangements essentially introduced bilateral trading by dividing the electricity market into the following areas: forward and future markets, where suppliers make agreements with producers based on their estimates of demand; a power exchange, where suppliers buy and sell electricity according to signed contracts; and finally, a balancing market, which is a short-term electricity spot market that allows producers and suppliers to make up any last minute shortfalls in supply caused, for example, by sudden changes in weather conditions. At the present time the available data cover only the operation of the balancing market, where about $5 \%$ of all electricity trades in England and Wales take place. No detailed micro data are available on bilateral trading between producers and suppliers. These circumstances limit the scope of the dissertation research to the pre-NETA period. 


\subsection{England and Wales Electricity Market}

The wholesale electricity market in England and Wales consisted of three participants: producers, the market operator, and retail suppliers. Each of the participants is characterized below.

An electricity producer owns one or several plants that can use single or multiple types of input. Each plant is usually divided into several equally-sized production units. An exception may be plants that are either already too small or using multiple types of input. In Figure 2.3 I present, as an example, the structure of National Power during January 2000. For each plant, I also provide information on the input type and the number of production units.

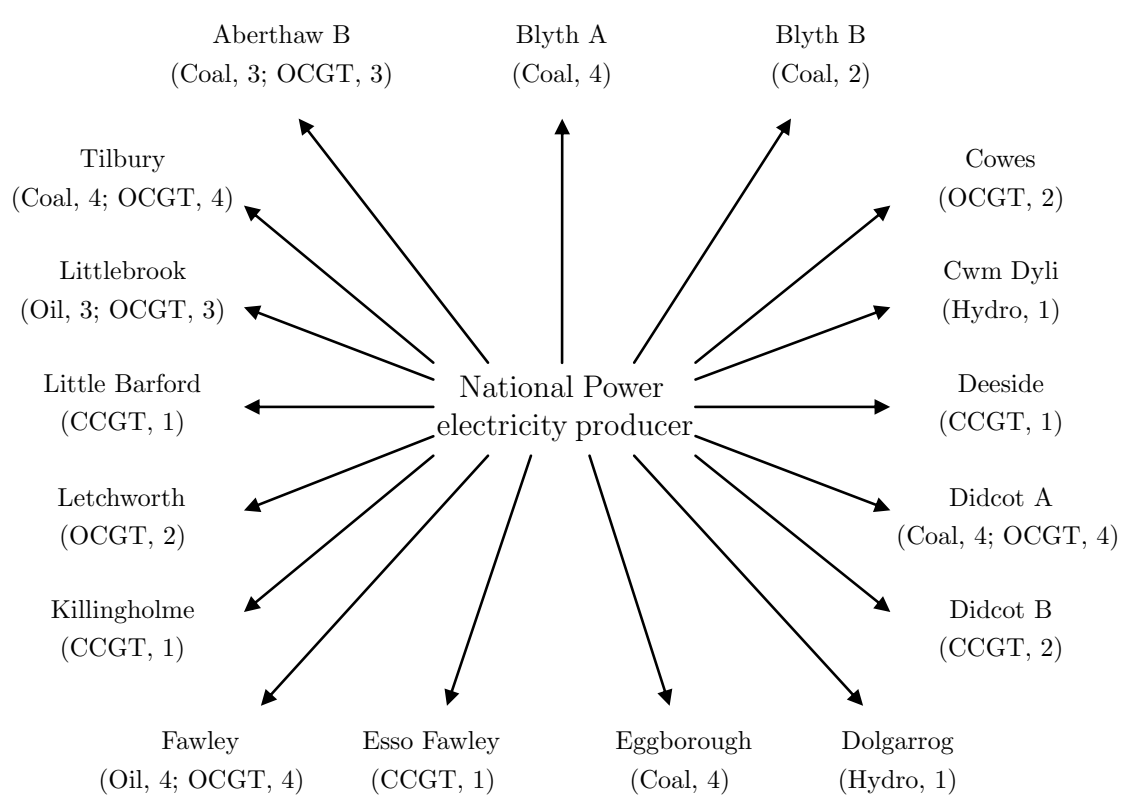

Source: Data sets described in Section 3.4; author's illustration.

Figure 2.3: Structure of National Power

Electricity producers sell electricity to retail suppliers through the wholesale market, which is also known as the Electricity Pool. This wholesale electricity market was managed by the network operator, the National Grid Company (NGC).

Trading in the England and Wales wholesale electricity market was conducted every day through a uniform price auction. The trading day consisted of 48 half-hourly trading periods, which the NGC divided into high- and low-demand trading periods. ${ }^{3}$ The NGC

\footnotetext{
${ }^{3}$ For the analysis of the exercise of market power, I consider the bidding behavior of electricity producers during the first five highest-demand trading periods.
} 
invited electricity producers to submit daily and half-hourly bids for each production unit for the following trading day.

The daily bids for each individual production unit included a start-up cost, a no-load cost, (at most) three incremental price bids, and two elbow points. The start-up cost (measured in £) represented the cost to start up a production unit. The no-load cost (measured in $£ / h$ ) represented the cost to keep a production unit from shutting down. The two elbow points (measured in MW) defined ranges over which the incremental price bids (measured in £/MWh) applied. In Figure 2.4, using data from January 14, 2000, I provide an example of what PowerGen submitted for its coal production unit KINO_02Z, which belonged to the Kingsnorth plant. The submitted bids for the start-up and no-load costs for this production unit were $£ 4,200$ and $£ 5,103 / \mathrm{h}$, respectively.

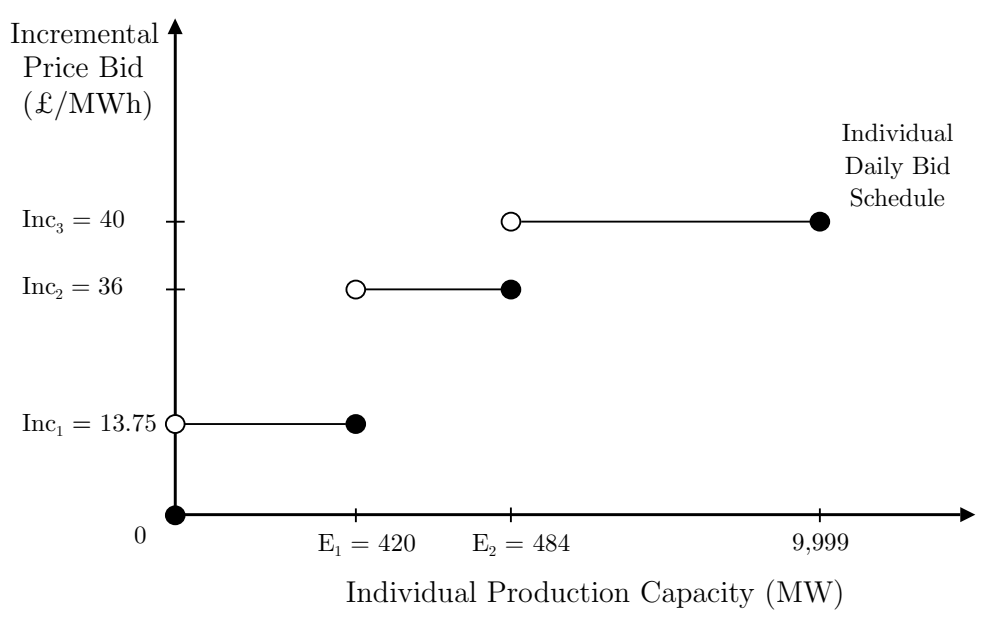

Source: Data set 2 described in Section 3.4; author's illustration.

Figure 2.4: Submission of Daily Bids by PowerGen (January 14, 2000)

Electricity producers were also asked to submit for each individual production unit half-hourly bids on production capacity (measured in MW). Since the duration of a trading period was half an hour, it follows that a production unit with a production capacity of, for example, $40 \mathrm{MW}$ during this time can produce $40 \mathrm{MW} \cdot \frac{1}{2} \mathrm{~h}=20 \mathrm{MWh}$ of electricity.

All these submitted daily and half-hourly bid data for individual production units were then used to compute the respective half-hourly price bids (PBs) for the next trading day. The computation of PBs measured in $£ / M W h$ was common knowledge and was also different for high- and low-demand trading periods.

Before describing the computation of PBs, I would like to stress two important im- 
plications following from the market rules. Firstly, since the submission of bids is at the level of individual production units, it follows that the computation of the PB for a certain production unit depends only on daily and half-hourly bids for that production unit. Secondly, since the computation of the PB depends on daily and half-hourly bids, it follows that the computed PB for a production unit should differ across half hours.

In the following paragraphs, in an intuitive way I try to provide a description of how half-hourly PBs were computed by the market operator (the NGC). The complete description of the algorithm used to transform daily and half-hourly bids into a halfhourly $\mathrm{PB}$ for each production unit is common knowledge and is described in Electricity Pool (1990). Here I have decided to use more intuitive names and representations for the different technical concepts and formulas used in Electricity Pool (1990).

Let $I n c_{1}, I n c_{2}, I n c_{3}$ denote three incremental price bids, $E_{1}$ and $E_{2}$ denote two elbow points, and $k$ denote production capacity. For high-demand trading periods the Average Bids (ABs) are first constructed:

1) if $k=0$, then $\left\{\begin{array}{l}A B_{1}=£ 0 / \mathrm{MWh} \\ A B_{2}=£ 999 / \mathrm{MWh} ; \\ A B_{3}=£ 999 / \mathrm{MWh}\end{array}\right.$;

2) if $k \in\left(0 ; E_{1}\right]$, then $\left\{\begin{array}{l}A B_{1}=\frac{\text { NoLoad }}{k}+\text { Inc }_{1} \\ A B_{2}=999 \\ A B_{3}=999\end{array}\right.$;

3) if $k \in\left(E_{1} ; E_{2}\right]$, then $\left\{\begin{array}{l}A B_{1}=\frac{\text { NoLoad }}{E_{1}}+I n c_{1} \\ A B_{2}=\frac{\text { Noood }}{k}+\frac{\text { Inc1 } \cdot E_{1}+I n c_{2} \cdot\left(k-E_{1}\right)}{k} \\ A B_{3}=999\end{array}\right.$;

4) if $k \in\left(E_{2} ; 9999 \mathrm{MW}\right]$, then $\left\{\begin{array}{l}A B_{1}=\frac{\text { NoLoad }}{E_{1}}+I n c_{1} \\ A B_{2}=\frac{\text { NoLoad }}{E_{2}}+\frac{I n c_{1} \cdot E_{1}+I n c_{2} \cdot\left(E_{2}-E_{1}\right)}{E_{2}} \\ A B_{3}=\frac{\text { NoLoad }}{k}+\frac{\text { Inc } c_{1} \cdot E_{1}+I n c_{2} \cdot\left(E_{2}-E_{1}\right)+I n c_{3} \cdot\left(k-E_{2}\right)}{k}\end{array}\right.$.

This choice of presentation allows interpreting $A B=\frac{\text { NoLoad }}{k}+\frac{I n c_{1} \cdot E_{1}+I n c_{2} \cdot\left(E_{2}-E_{1}\right)+I n c_{3} \cdot\left(k-E_{2}\right)}{k}$, for example, as consisting of two components. The first component uniformly distributes the no-load cost over the production capacity and the second term is essentially a capacity-weighted average of submitted incremental price bids. Similarly, it can be shown that the start-up cost is uniformly distributed over high-demand trading periods 
during which a production unit produces electricity and then added to the half-hourly ABs. Depending on the value of production capacity $k$ for each production unit, the minimum among the final $A B_{1}, A B_{2}$, and $A B_{3}$ define the half-hourly PBs.

In low-demand trading periods, the $\mathrm{PB}$ is set equal to one of the incremental price bids depending on the value of the submitted half-hourly production capacity $k$ :

1) if $k=0$, then $P B=0$;

2) if $k \in\left(0 ; E_{1}\right]$, then $P B=I n c_{1}$;

$3)$ if $k \in\left(E_{1} ; E_{2}\right]$, then $P B=I n c_{2}$;

4) if $k \in\left(E_{2} ; 9999 \mathrm{MW}\right.$, then $P B=I n c_{3}$.

For each half-hourly trading period, the pairs of the $\mathrm{PB}$ and respective production capacity are ordered based on the PB to construct an aggregate supply schedule that would indicate the least expensive way to meet a price-inelastic forecasted demand. The constructed aggregate supply schedule is also called a merit order. The production unit whose PB in this merit order intersects the price-inelastic forecasted demand is called the marginal production unit. Its respective PB is called the System Marginal Price (SMP). Production units located to the left of the forecasted demand are called infra-marginal production units. Finally, production units located to the right of the forecasted demand are called extra-marginal production units.

Figure 2.5 is a hypothetical example of how the wholesale electricity market would have operated in a given trading period.

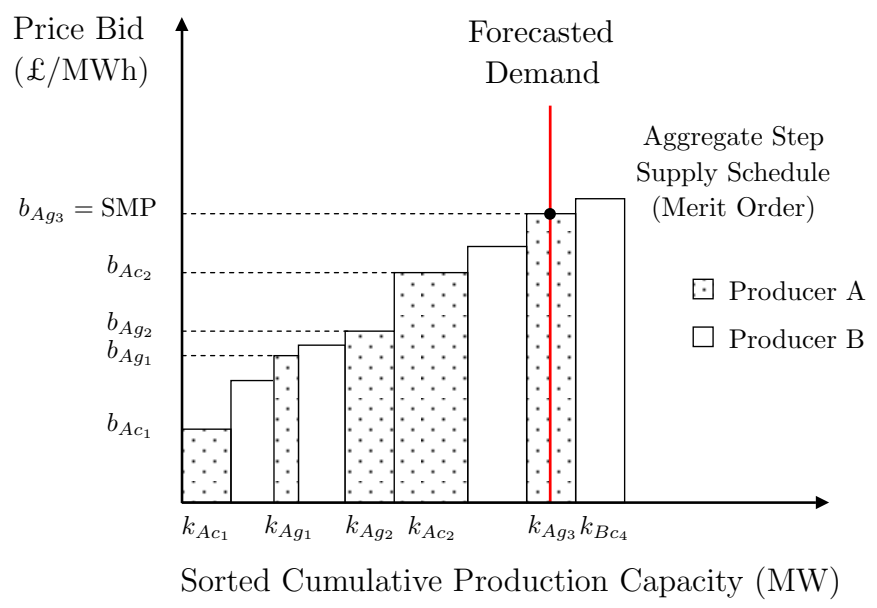

Source: Author's illustration.

Figure 2.5: Determination of the System Marginal Price: A Hypothetical Example

The vertical line in the graph is the forecasted demand, which is measured in MW, not in MWh. The price-inelastic forecasted demand is prepared by the market operator (i.e., 
the National Grid Company (NGC)), whose forecasting methodology is also common knowledge (see, for example, Wolak, 2000; Wolak and Patrick, 2001).

Let $b_{A c_{1}}$ denote the $\mathrm{PB}$ of electricity producer A's first production unit of type $c$, whose submitted production capacity is $k_{A c_{1}}$ (similarly for $b_{A g_{1}}$ and $b_{B c_{1}}$ ). For illustration purposes, it is assumed that electricity producer $\mathrm{A}$ has two coal and three gas production units and electricity producer B has four coal production units. The PBs of all production units belonging to producers $\mathrm{A}$ and $\mathrm{B}$ are ordered as would have been done by the market operator to create the aggregate step supply schedule, i.e., the merit order. The intersection of the price-inelastic forecasted demand and the constructed merit order determines the SMP.

In this hypothetical example, in particular, the first four coal and gas production units of electricity producer A are the infra-marginal production units. The third gas production unit of electricity producer $\mathrm{A}$ is the marginal production unit that determines the SMP.

In Figure 2.6, I illustrate an actual example of the determination of the marginal production unit and the SMP.

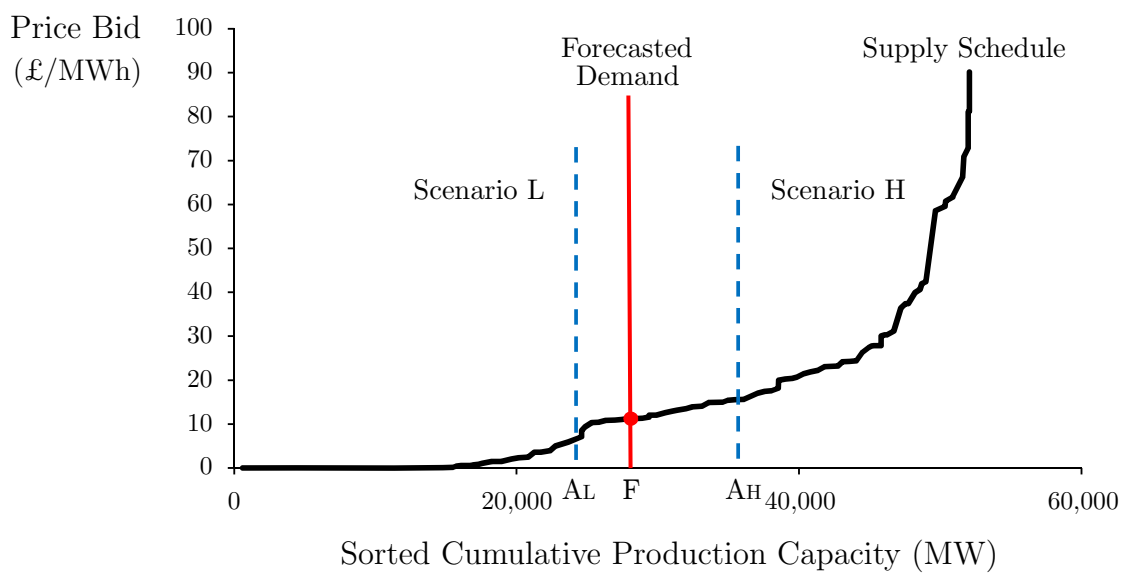

Source: Data sets described in Section 3.4; author's calculations.

Notes: The trading period during 23:00-23:30 on January 14, 2000 is considered. Production units with PBs higher than $£ 100 / \mathrm{MWh}$ are not depicted due to the scale problem. Scenario L and Scenario H describe a possible realization of the actual demand.

Figure 2.6: Determination of the System Marginal Price

The observed zero values for PBs close to the origin in Figure 2.6 can be explained. Nuclear and combined cycle gas turbine (CCGT) production units have low operating costs and therefore operate as the base-load and almost constantly. This implies that those types of production unit are often positioned close to the origin of the aggregate 
supply schedule and are therefore far from setting the SMP. Moreover, it is costly to turn those production units on and off (especially nuclear production units). That is why, as an attempt to ensure that those types of production unit are scheduled to produce electricity, producers frequently submit zero price bids. Such a behavior of electricity producers could therefore be characterized as free riding on the SMP, that is, receiving the uniform auction price even without actively bidding in the auction (see, for example, Edwards, 2010).

As depicted in Figure 2.6, the forecasted demand for the trading period under consideration is 34,585 MW. The intersection of the constructed merit order and forecasted demand determines an SMP equal to $£ 15 /$ MWh. It is set by a production unit belonging to the EdF electricity producer.

Below I describe in detail other payments whose computation is dependent on the outcome of the uniform auction price, i.e., the SMP.

Electricity producers that declare their production units available and are scheduled to produce electricity during high-demand trading periods in addition to the SMP receive a Capacity Payment (CP). The $\mathrm{CP}$ is an additional payment to stimulate electricity producers to make their production capacity available to the system during high-demand trading periods. The payment is high at times when there is little spare production capacity available. Therefore, from the perspective of producers, this payment could also be interpreted as scarcity rent. The CP is computed based on the Loss of Load Probability (LOLP), the Value of Lost Load (VLL), and the SMP. The LOLP is an estimated probability that demand will exceed the total production capacity (a measure reflecting reliability of electricity supply) and the VLL is the Pool's estimate of customers' maximum willingness to pay for electricity supply. Customers that require high reliability of electricity supply are, for example, airports, hospitals, and farms for which it is very costly to experience power outages.

Thus, electricity producers that declare their production units available and are eventually scheduled to produce electricity during high-demand trading periods receive the Pool Purchase Price (PPP), which is equal to the sum of the SMP and CP :

$$
\mathrm{PPP}=\mathrm{SMP}+\mathrm{CP}=\mathrm{SMP}+\mathrm{LOLP} \cdot \max \{0, \mathrm{VLL}-\mathrm{SMP}\}
$$

Otherwise, electricity producers that declare their production units available and are scheduled to produce electricity during low-demand trading periods receive only the SMP payment. 
As described earlier, the SMP is determined from the intersection of the merit order and forecasted demand. In reality, however, the forecasted demand need not be the same as the actual demand. As described in Figure 2.6, two possible scenarios can arise: Actual Demand $<$ Forecasted Demand (i.e., $A_{L}<F$ ) and Actual Demand $>$ Forecasted Demand (i.e., $A_{H}>F$ ).

On the one hand, under scenario $L$, when $A_{L}<F$, the market rules require that all production units located in $\left[A_{L} ; F\right]$ be compensated by SMP less their PBs. On the other hand, under scenario $H$, when $A_{H}>F$, the market rules require that all production units located in $\left[F ; A_{H}\right]$ be paid their PBs. The compensation scheme for a production unit $i$ under low and high scenarios can therefore be summarized as follows:

$$
\begin{cases}\text { Payment }_{i}=\mathrm{SMP}-\mathrm{PB}_{i}, & \text { scenario } L \\ \text { Payment }_{i}=\mathrm{PB}_{i}, & \text { scenario } H .\end{cases}
$$

Retail suppliers buying electricity from the wholesale market pay the Pool Selling Price (PSP), which only during high-demand trading periods in addition to the PPP includes the Uplift. The Uplift covers costs for reserves, ancillary services, etc.:

$$
\mathrm{PSP}=\mathrm{PPP}+\mathrm{Uplift}=\mathrm{SMP}+\mathrm{CP}+\mathrm{Uplift} .
$$

The regulatory authority was primarily concerned about the SMP since in the wholesale electricity market it is the equilibrium outcome that depends on the bidding behavior of electricity producers and the forecasted demand. Attempts to increase competition through the regulatory reforms were directed at eventually providing lower prices for customers. 


\section{Analysis of Electricity Industry Liberalization in Great Britain: How Did the Bidding Behavior of Electricity Producers Change?}

\subsection{Introduction}

At the start of the liberalization of the electricity supply industry in Great Britain, a wholesale market for electricity trading was created in England and Wales. Trading was organized as a uniform price auction, where electricity producers are asked to bid prices at which they are willing to produce electricity. The regulatory authority, the Office of Electricity Regulation (OFFER), believed that electricity producers exercised market power by submitting price bids significantly exceeding marginal costs.

An exercise of market power leads to higher uniform auction prices (i.e., the System Marginal Price (SMP)) and, therefore, higher revenues for electricity producers. On the other hand, a higher SMP increases payments by retail suppliers, which are, in the end, reflected in higher prices paid by consumers. Another consequence of an exercise of market power are the possible losses in the efficient allocation of production facilities. In other words, due to possible differences in setting bid markups, there need no longer be any guarantee that, based on ordered price bids, the least cost production facilities are indeed scheduled to produce electricity.

These issues of an exercise of market power are also discussed in Bergman et al. (1998) in the analysis of the first form of benefits that electricity market reforms could bring to consumers: lower prices resulting from lower price-cost margins and more cost-efficient production of electricity. The other forms of benefits that electricity market reforms could bring to consumers include a high degree of security of supply and an environmentally friendly electricity supply system, which in the long run would not critically depend on exhaustible natural resources.

Figure 3.1 describes the half-hourly changes of the uniform auction price (i.e., the SMP) and forecasted demand during January 13, 2000 - January 14, 2000. The computed correlation coefficient between the price and demand during those two representative consecutive business days is about 0.81 . This provides evidence of a high level of comovement between the price and demand series.

As described in Figure 3.1, the SMP and forecasted demand change in the ranges of $£ 10 / \mathrm{MWh}$ to $£ 75 / \mathrm{MWh}$ and $35,000 \mathrm{MW}$ to 50,000 MW, respectively. However, it is interesting to observe large price changes within the small neighborhood of the 
highest-demand trading periods, which coincided with the time in the evenings when people usually return home. In particular, on January 13, 2000, the SMP during the highest-demand trading period (when the forecasted demand was 48,975 MW) is about $£ 72.66 /$ MWh, whereas, for example, just two trading periods earlier (when the forecasted demand is $48,442 \mathrm{MW}$, which is less by about $1 \%$ compared to $48,975 \mathrm{MW}$ ), the respective SMP is $£ 33.2 /$ MWh. A similar event took place the next business day too.

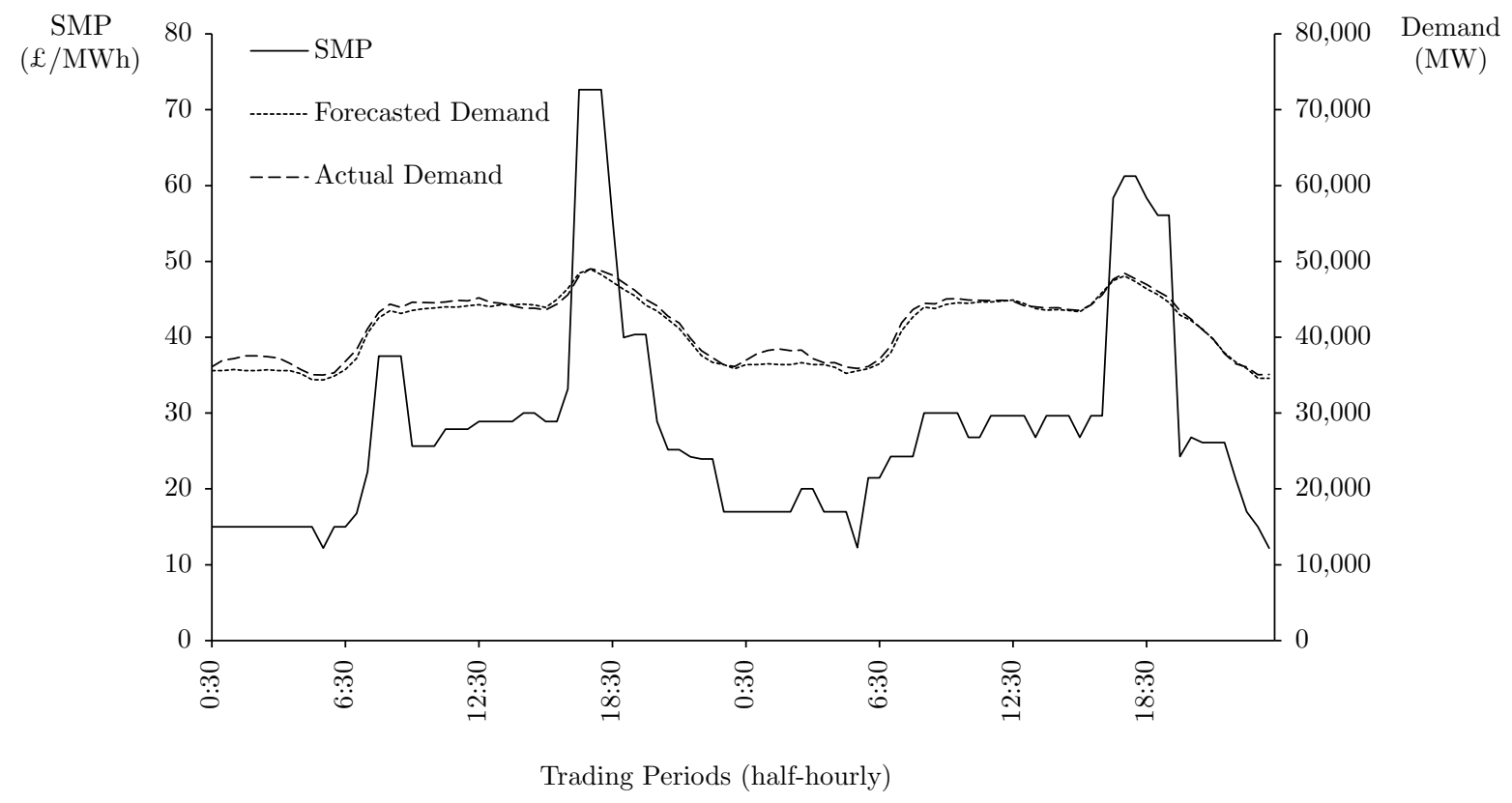

Source: Data set 1 described in Section 3.4; author's calculations.

Figure 3.1: SMP and Demand for Electricity (January 13, 2000 - January 14, 2000)

The regulatory authority believed that wholesale electricity prices at times were significantly higher than expected. The excessively high prices were attributed to the possible exercise of market power by the two incumbent electricity producers: National Power and PowerGen. Hence, to mitigate the exercise of market power and increase competition among electricity producers, several reforms were introduced. Based on the analysis of the bidding behavior of electricity producers during the highest-demand trading periods, I empirically evaluate to what extent the reforms introduced by the OFFER were successful at mitigating the exercise of market power and at fostering competition among producers during 1995-2000. 


\subsection{Literature Review}

Von der Fehr and Harbord (1993) is the seminal research in modeling electricity auctions. In their research, the authors assume that $N$ electricity producers serve the British electricity market operated as a uniform price auction. The authors also assume that marginal costs are common knowledge and differ only across electricity producers. This assumption implies that all production units of a certain electricity producer have the same marginal costs, which can be partly supported by the fact that during the early 1990s about $70 \%$ of production capacity was based on coal (see Figure C.1). However, this assumption is still subject to criticism because the thermal efficiency rates of different coal production units belonging to a certain electricity producer need not be the same.

The authors demonstrate that no pure-strategy bidding equilibrium exists when electricity demand falls within a certain range. Their result is explained by an electricity producer's conflicting incentives to bid high in order to set a high price and to bid low in order to ensure that its production unit is scheduled to produce electricity.

Wolfram (1998) empirically examines the bidding behavior of electricity producers in the same electricity market. As a benchmark model she analyzes a duopoly case, where the first producer has several production units and the second producer has one

production unit. From the profit maximization problem the author derives an optimality condition, the intuition and conclusions of which are then used in the construction of a regression model.

The main finding of Wolfram (1998) is that electricity producers submit price bids reflecting higher markups for production units that are likely to be scheduled to produce electricity if that producer has a large infra-marginal production capacity. The author indicates (using the optimality condition) that the incentive to submit a price bid reflecting a higher markup for a certain production unit is moderated by the presence of the threat that the production unit might not be scheduled to produce electricity. Wolfram (1998) also finds that larger producers submit higher price bids than smaller producers for comparable production units (i.e., production units using the same input to produce electricity and having almost the same marginal costs).

The findings of Wolfram (1998) are in line with the findings of Green and Newbery (1992), which is a seminal study using the framework of supply function equilibrium (SFE) for the England and Wales electricity market. This framework assumes that each producer submits a continuous supply function, which is applicable when producers' production units are small enough or when each producer has a sufficiently large number 
of production units as was the case, for example, with National Power and PowerGen in England and Wales. Green and Newbery (1992), using the concept of SFE for a duopoly model, show that a larger producer (National Power) tended to submit price bids reflecting higher markups than did a smaller producer (PowerGen). This finding, therefore, also illustrates the case that a producer with a larger infra-marginal capacity has more incentive to increase its price bid.

Crawford et al. (2007) extend the work of Von der Fehr and Harbord (1993) by allowing production units belonging to a particular electricity producer to have different marginal costs. Similar to Von der Fehr and Harbord (1993), Crawford et al. (2007) assume complete information about the marginal costs of electricity producers because it was possible to approximate them using data on the thermal efficiency rates of production units (they were published just before the liberalization of the electricity supply industry in Great Britain) and input prices (they were published by the Department of Trade and Industry, January 1993 - December 2000).

For some production units, even updated estimates of thermal efficiency rates are available. In general, it is not surprising to expect thermal efficiency rates to change over time because increasing competition among electricity producers stimulated improvement in productive efficiency, which suggested a decrease in marginal costs and driving out expensive and less productive facilities. Using, however, older thermal efficiency rates could, at times, overestimate the true marginal costs, leading, thereby, to a measurement error.

Crawford et al. (2007) also assume no demand uncertainty (this assumption is supported by the commonly known forecasting methodology stated in Wolak, 2000; Wolak and Patrick, 2001) and that no electricity producer is able to serve the whole demand (this assumption is supported by the data on market demand and an individual electricity producer's total production capacity). In their research the authors empirically establish the presence of asymmetries in the bidding behavior of marginal and inframarginal electricity producers in the British electricity market during 1993-1995: during the highest-demand trading periods marginal electricity producers behave strategically by submitting price bids higher than their marginal costs, whereas infra-marginal electricity producers behave competitively by submitting price bids reflecting their marginal costs.

For the following period of 1995-2000, Sweeting (2007) analyzes the development of market power in the same electricity market. The author measures market power as the margin between observed wholesale market prices and estimates of competitive 
benchmark prices, where the latter is defined as the expected marginal cost of the highestcost production unit required to meet electricity demand. Sweeting (2007) finds that electricity producers were exercising increased market power during 1995-2000. This finding, as the author indicates, is however in contradiction with oligopoly models, which, given that during this period market concentration was falling, would have predicted a reduction in market power.

As explained in Borenstein et al. (2002), the application of competitive benchmark prices to analyze whether an electricity market, as a whole, is setting competitive prices has an advantage of being less vulnerable to the arguments of coincidence and bad luck. This approach also allows estimating the scope and severity of departures from competitive bidding over time.

However, the application of competitive benchmark prices does not allow one to analyze in more detail specific manifestations of noncompetitive bidding behavior for different electricity producers. In order to detect the individual attempts of producers to affect prices, I follow an alternative approach similar to Wolfram (1998) and Crawford et al. (2007). More precisely, to analyze the development of the exercise of market power in relation to the reforms introduced by the regulatory authority, I consider the bidding behavior of individual electricity producers with respect to marginal and extra-marginal production units during the highest-demand trading periods.

For my ex-post regulation analysis, the choice of production units located at or close to the forecasted demand is in line with findings in Wolfram (1998) and Crawford et al. (2007) that it is namely these production units which could potentially be used for strategic bidding and an exercise of market power. The approach to selectively focus on a certain trading period is in line with the methodology adopted in Crawford et al. (2007) and Sweeting (2007). Crawford et al. (2007), in particular, focus on the highestdemand trading periods and Sweeting (2007), on the other hand, considers Wednesdays as a representative weekday. The choice of the highest-demand trading periods to analyze the development of the bidding behavior of electricity producers in relation to the introduced regulatory reforms (described in detail in Section 2.1) is also in agreement with the finding of Borenstein et al. (2002), where the authors, using the example of the wholesale electricity market in California, demonstrate that market power is most commonly exercised during high-demand trading periods. 


\subsection{Methodology}

For the analysis of the bidding behavior of electricity producers, I first describe the assumptions and research approach. Then I analyze a duopoly case with an asymmetric technology structure. Based on the conclusions obtained from the optimality condition in a duopoly case and partly on economic intuition, I develop a regression model to analyze the bidding behavior of electricity producers with respect to marginal and extramarginal production units. This analysis allows to empirically evaluate the success of the reforms introduced by the regulatory authority to foster competition among electricity producers during 1995-2000. A similar specification, named a bid markup equation, is also analyzed in Wolfram (1998) and Crawford et al. (2007). In order to compute bid markups, a knowledge of marginal costs is required. The proposed approach to approximate marginal costs concludes the methodology.

\subsubsection{Assumptions and Research Approach}

For the analysis of the influence of particular regulatory reforms on the development of the bidding behavior of electricity producers, I assume no uncertainty in the forecasted demand for electricity and that the marginal costs of electricity production can be approximated.

The first assumption is based on the fact that the methodology the market operator (i.e., the National Grid Company) applied to forecast electricity demand for each trading period of the following trading day was common knowledge (see, for example, Wolak, 2000; Wolak and Patrick, 2001). In addition, it is worth mentioning that the forecasting methodology applied by the market operator was very precise. In particular, for example, during January 13, 2000 - January 14, 2000, the computed correlation coefficient between the forecasted and actual demand for electricity was almost unity (see Figure 3.1).

The second assumption is based on the availability of data describing the technical characteristics (i.e., the thermal efficiency rate and input type) of production units. In particular, the marginal costs of production units using coal, oil, or gas as their inputs are approximated using data on thermal efficiency rates and input prices. The definition of the thermal efficiency rate and data on quarterly input prices are provided by the Department of Trade and Industry (1997-2002, January 1993 - December 2000). These are described in detail in Section 3.3.4.

The approximated marginal costs of production units are then used in the ex-post analysis of the bidding behavior of electricity producers with respect to marginal and 
extra-marginal production units during the highest-demand trading periods. The specification of the regression model in the empirical analysis follows from the conclusions of the optimality condition of a profit-maximizing producer and partly from economic intuition. For the robustness check I also analyze the bidding behavior of electricity producers during the second-fifth highest-demand trading periods.

\subsubsection{Analysis of a Duopoly Case with an Asymmetric Technology Structure}

General solutions for electricity auction markets to my knowledge have not been analyzed in detail. This is related to the fact that the general setup of trading in electricity auctions would represent a complex game, where the existence and uniqueness of equilibrium bidding strategies of a potentially large number of heterogeneous producers are open questions (see, for example, Von der Fehr and Harbord, 1993). Focusing on the case of symmetric producers might, however, be of little practical value in the evaluation of reforms because that construction would be far from describing the real market: the bidding strategies of electricity producers using coal and gas types of input need not be the same.

The number of producers is another important issue in modeling electricity markets. For example, Anderson and Xu (2004) model the Australian electricity market as a twoplayer game and mention that this is the main limitation of their research. The authors also state that the situation with three or more electricity producers becomes much harder to analyze.

It is also worth mentioning the two key properties of electricity, which make the analysis of electricity markets special. First of all, electricity is a perfectly homogeneous product, which means that neither retail suppliers nor consumers can tell by which producer or by which input type the electricity was produced. Secondly, electricity is a nonstorable product, which creates a necessity to coordinate supply and demand on a continuous basis with the highest precision possible. For the case of England and Wales, to account for this feature, half-hourly trading periods were organized. As described in Section 2.2, the market operator was responsible for managing the exchange of electricity between producers and retail suppliers through a uniform price auction by preparing the forecasted demand and determining day-ahead half-hourly prices.

Similar to Wolfram (1998) and Crawford et al. (2007), to circumvent these issues I consider a duopoly case with two electricity producers with the main distinction that I analyze at the level of the type of production unit. This modeling approach allows 
to analyze the behavior of individual electricity producers with respect to marginal or extra-marginal production units of different types that are identified using the forecasted demand. This is needed for the ex-post evaluation of the impact of the reforms introduced by the regulatory authority to mitigate the exercise of market power and foster competition among electricity producers. Namely marginal or extra-marginal production units of different input types located at or close to forecasted demand could likely be used for strategic bidding because of being potential candidates to use to set a uniform auction price.

Let us assume the presence of two risk-neutral electricity producers A and B. Assume that electricity producer A has several types of production unit (e.g., National Power uses coal, oil, gas, and hydro types of production unit as described in Table B.5), whereas electricity producer $\mathrm{B}$ has just one type of production unit. The assumption about electricity producer B having just one type of production unit is, for example, supported partly by the structure of British Energy. As summarized in Table B.5, this producer has ten nuclear (operated usually as the base-load) and four coal production units. The coal type of production unit could indeed set the uniform auction price in line, for example, with National Power.

For the explanation of the model I refer to the example in Figure 3.2, which is similar to the hypothetical example presented in Section 2.2. More general cases demand complex notations, which may complicate the illustration of derivation results important for the construction of the regression model described in Section 3.3.3.

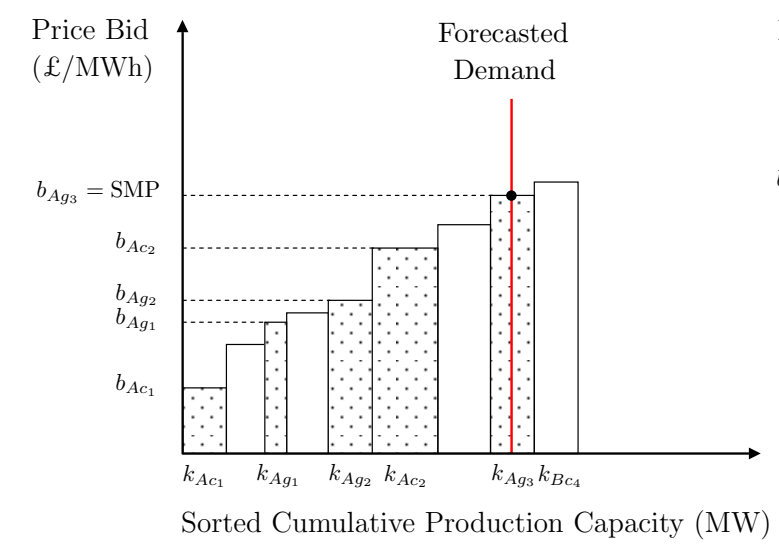

(a) Producer A sets the uniform price

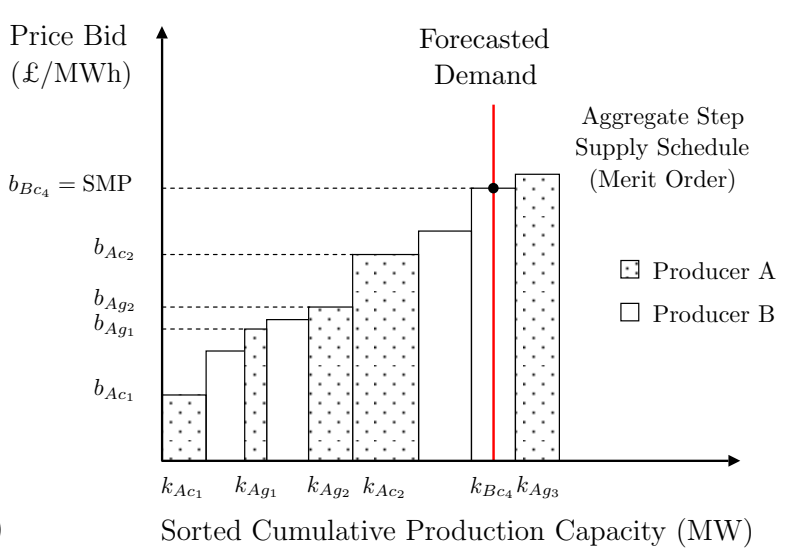

(b) Producer B sets the uniform price

Source: Author's illustration.

Figure 3.2: Determination of the System Marginal Price: A Hypothetical Example 
Let $k_{A \tau}$ denote the production capacity of type $\tau$ belonging to producer $\mathrm{A}$ that is declared available to produce electricity. More precisely, $k_{A \tau}$ is the overall capacity of production units of type $\tau$ from the supply schedule constructed by the market operator (i.e., the auctioneer). For the example described in Figure 3.2, it follows that $k_{A c}=$ $k_{A c_{1}}+k_{A c_{2}}, k_{A g}=k_{A g_{1}}+k_{A g_{2}}+k_{A g_{3}}, k_{B c}=k_{B c_{1}}+k_{B c_{2}}+k_{B c_{3}}+k_{B c_{4}}$.

Let $c_{A \tau}$ denote the marginal cost of producer A's highest-cost production unit of type $\tau$. For the hypothetical example this would mean that $c_{A c}=c_{A c_{2}}, c_{A g}=c_{A g_{3}}$, and $c_{B c}=c_{B c_{4}}$. Setting the marginal costs of all production units of type $\tau$ by the marginal cost of the most expensive production unit in the calculation of expected profits is partly similar to the concept of competitive benchmark prices used in Sweeting (2007). The marginal costs of production units are approximated based on the methodology described in Section 3.3.4.

Let $b_{B}$ denote producer B's price bid submitted for the highest-cost production unit. Because producer $\mathrm{B}$ is assumed to have only one type of production unit the subscript for the type is omitted. Assume that the probability distribution of $b_{B}$ is defined according to a cumulative distribution function $F\left(b_{B}\right)$ and the respective probability density function $f\left(b_{B}\right)$ with support on the compact interval $[\underline{b}, \bar{b}]$, where $\underline{b}, \bar{b} \in \mathbb{R}^{+}$and $\underline{b}<\bar{b}$. This is assumed to be common knowledge.

Similarly, let $b_{A \tau}$ denote producer A's price bid submitted for the highest-cost production unit of type $\tau$. For a simplified example described in Figure 3.2, it is the price bid of the third gas production unit that could be used for strategic manipulation by producer A. In other words, $b_{A g} \in[\underline{b}, \bar{b}]$ is producer A's strategic choice variable.

Submitted capacity bids and price bids for individual production units represent private knowledge for each producer that owns those production units. This is a feature of a sealed-bid uniform-price auction, where the bids of one producer are unknown to the other producers.

The payoff of a producer is represented by an expected profit, which is dependent on the outcome of the uniform price auction (i.e., who sets the uniform auction price), the amount of electricity a producer sells at the market, and production costs. More precisely, given the bid $b_{B}$ of producer $\mathrm{B}$, let us define the expected profit maximization problem of producer A: 


$$
\begin{aligned}
E\left[\pi_{A}\left(b_{A g}, b_{B}\right)\right] & =E[\pi_{A} \mid \underbrace{b_{B}>b_{A g}}_{\text {A sets }}]+E[\pi_{A} \mid \underbrace{b_{B} \leq b_{A g}}_{\text {B sets }}]= \\
& =\int_{b_{A g}}^{\bar{b}}\left[\left(b_{A g}-c_{A c}\right) \cdot \frac{1}{2} k_{A c}+\left(b_{A g}-c_{A g}\right) \cdot \frac{1}{2} k_{A g}\right] \cdot f\left(b_{B}\right) d b_{B}+ \\
& +\int_{\underline{b}}^{b_{A g}}\left[\left(b_{B}-c_{A c}\right) \cdot \frac{1}{2} k_{A c}+\left(b_{B}-c_{A g}\right) \cdot \frac{1}{2} \alpha_{A g} k_{A g}\right] \cdot f\left(b_{B}\right) d b_{B} .
\end{aligned}
$$

In the calculation of the expected profit, producer A considers two possible scenarios depending on who sets the uniform auction price as is described in Figure 3.2. If producer A sets the price, the uniform auction price is $b_{A g}$. However, if producer B sets the price, the uniform auction price is $b_{B}$ and only $\alpha_{A g}$ part of the submitted gas production capacity belonging to producer $\mathrm{A}$ will be scheduled to produce electricity.

I use a factor of $\frac{1}{2}$ to convert MW to MWh. This follows from the fact that the duration of a trading period is 30 minutes. A production capacity of, for example, 40 MW multiplied by this time gives the amount of electricity produced by a production unit during a half-hour period: $40 \mathrm{MW} \cdot \frac{1}{2} \mathrm{~h}=20 \mathrm{MWh}$.

Taking the first-order condition with respect to $b_{A g}$ and rearranging leads to $\log \left(b_{A g}-c_{A g}\right)=\log \left(k_{A c}+k_{A g}\right)-\log \left(1-\alpha_{A g}\right) k_{A g}+\log \left(1-F\left(b_{A g}\right)\right)-\log \left(f\left(b_{A g}\right)\right)$.

In the optimality condition, $b_{A g}-c_{A g}$ denotes the markup defined as the price bid minus the approximated marginal cost of the production unit of type $g$ that belongs to producer A. The methodology to approximate marginal costs of production units is reviewed in Section 3.3.4.

$k_{A c}+k_{A g}$ denotes the total capacity of production units located up to price bid $b_{A g}$ in the supply schedule constructed by the market operator (i.e., the auctioneer). The optimality condition suggests that a larger total production capacity creates an incentive to submit a higher price bid, which is a valid statement because when that price bid sets the uniform auction price it is applied to producer A's total production capacity. Similar intuition is also provided in Mount (2001), where the author states that the increasing difference between the price bid and marginal cost observed when the number of units 
for sale increases is an example of how market power can be used to raise the final price.

However, the incentive to increase a price bid is moderated by the presence of risk that a production unit at stake may not eventually be scheduled to produce electricity. The next term in the optimality condition, $\left(1-\alpha_{A g}\right) k_{A g}$, denotes precisely a part of the production capacity of type $g$ belonging to producer A that might not be scheduled to produce electricity due to a significantly high price bid. A negative sign in the optimality condition reflects the presence of a trade-off when increasing the price bid, which is associated with profit losses caused by the production unit at stake not being scheduled to produce electricity. $f\left(b_{A g}\right)$ denotes the likelihood that a production unit of type $g$ that belongs to producer A becomes marginal. As the optimality condition suggests, a higher price bid decreases the likelihood of setting the uniform auction price, which therefore negatively affects the producer's incentive to submit an excessively high price bid. $1-F\left(b_{A g}\right)$ represents the probability that $b_{A g}$ sets the price. This probability is predicted to positively affect producer A's bid markup.

For an ex ante analysis, it is necessary to accurately estimate these probability values. The accurate estimation of these time-variant probability values is, however, a difficult task in the case of several producers. Besides the fact that these probability values are generally different across producers, they are also expected to vary across the types of input an individual producer can use for electricity production. However, for the assessment of the regulatory reforms, an ex-post analysis of the bidding behavior of electricity producers with respect to marginal and extra-marginal production units could have been more applicable. Given the market outcomes, I evaluate the success of the undertaken regulatory reforms directed at fostering competition among electricity producers.

The presented theoretical model suggests considering a log-linear functional relationship in the specification of a regression model to evaluate the success of the reforms aimed at improving competition in the wholesale electricity market in England and Wales.

\subsubsection{Specification of a Regression Model}

Based on the conclusions discussed in the analysis of a duopoly case at the level of the type of production unit and partly on economic intuition, we can formulate the following regression model to empirically analyze the bidding behavior of electricity producers:

$$
\begin{aligned}
\log \left(\text { Markup }_{i j t}\right) & =\beta_{0 i}+\beta_{1 i} \cdot \log \left(\text { Production Units below Bid } b_{i j t}\right)+\beta_{2 i j} \cdot \log \left(\text { Production Unit at Bid } b_{i j t}\right)+ \\
& +\sum_{l=1}^{5} \gamma_{l} \cdot \text { Day }_{l t}+\sum_{l=1}^{3} \theta_{l} \cdot \text { Season }_{l t}+\varepsilon_{i j t} .
\end{aligned}
$$


In this regression model, subscript $i$ stands for an electricity producer. Subscript $j$ stands for a marginal or extra-marginal production unit of type $j$. This means that producers' production units located at or above the forecasted demand are considered. If a producer has several production units of the same input type located at or above the forecasted demand, then only a production unit closest to the forecasted demand is considered. Finally, subscript $t$ stands for a half-hourly trading period. Trading periods are ordered according to the forecasted demand (from the highest to the lowest). This is done with a view to analyze and understand the strategic bidding behavior of producers during different high-demand trading periods. That is, I first analyze the bidding behavior of producers during only the highest-demand trading periods. Then, for a robustness check, I similarly consider the next four highest-demand trading periods.

The dependent variable, Markup $_{i j t}$, denotes the price bid minus the marginal cost of a production unit of type $j$ (could be a marginal or extra-marginal production unit of type $j$ ) belonging to producer $i$ during trading period $t$. There are two main reasons for specifying a markup as a dependent variable. Firstly, this allows analyzing an exercise of market power explained by other variables. Secondly, the calculation of a markup may involve a measurement error because of approximation of marginal costs. Therefore, considering a markup as a dependent variable, rather than as an explanatory variable, may at most lead to the overestimation of standard errors of coefficient estimates. A similar approach has also been considered in Wolfram (1998) and Crawford et al. (2007).

The two key explanatory variables in the regression model are Production Units below Bid $b_{i j t}$ and Production Unit at Bid $b_{i j t}$. Production Units below Bid $b_{i j t}$ denotes the total capacity of production units that belong to producer $i$ and have price bids lower than $b_{i j t}$. Production Unit at Bid $b_{i j t}$ denotes the capacity of a marginal or extra-marginal production unit of type $j$ for which producer $i$ submits price bid $b_{i j t}$.

In Figure 3.3, using an example of producer A with two types of production unit, I schematically illustrate the main variables used in the regression model.

The effect of the first key explanatory variable, measuring the total capacity of production units below the submitted price bid, is generally assumed to be different across producers. Moreover, the producer-specific slope parameter $\beta_{1}$ is expected to be positive because, as the theoretical predictions suggest, a larger total production capacity would create an incentive to submit a price bid reflecting a higher bid markup: when this price bid sets a uniform auction price, it is applied to a producer's entire scheduled production capacity. This intuition is also analyzed in Mount (2001), where the author states 


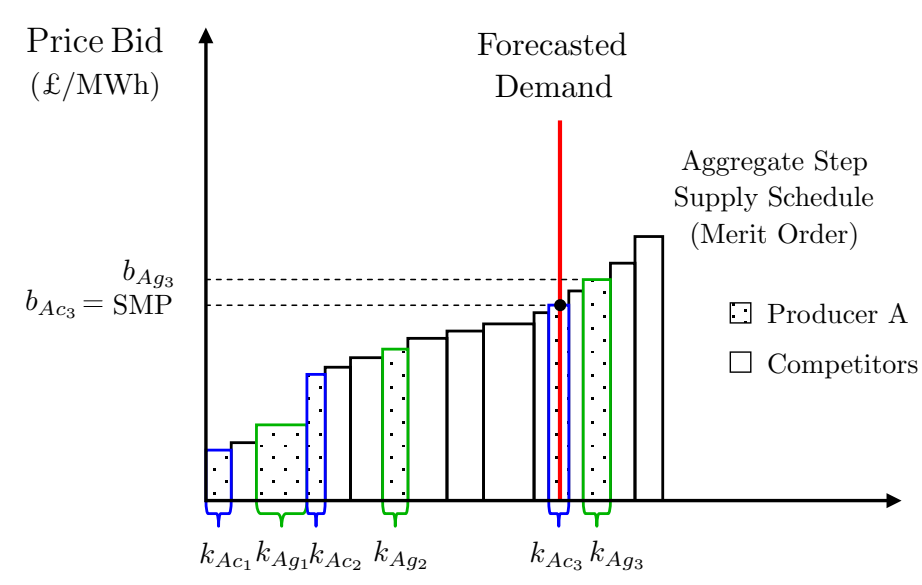

Sorted Cumulative Production Capacity (MW)

Source: Author's illustration.

Notes: Production Units below Bid $b_{A c_{3}}: \quad k_{A c_{1}}+k_{A g_{1}}+k_{A c_{2}}+k_{A g_{2}}$

Production Unit at Bid $b_{A_{3}}: \quad k_{A}$

Markup $_{A c_{3}}$ : $\quad b_{A c_{3}}-c_{A c_{3}}$

Production Units below Bid $b_{A g_{3}}: k_{A c_{1}}+k_{A g_{1}}+k_{A c_{2}}+k_{A g_{2}}+k_{A c_{3}}$

$\begin{array}{ll}{\text {Production Unit at Bid } b_{A g_{3}}:}^{\text {Markup }_{A g_{3}}:} & k_{A g_{3}} \\ & b_{A g_{3}}-c_{A g_{3}}\end{array}$

Figure 3.3: Explanation of Regression Variables

that the increasing difference between the price bid and marginal cost observed when the number of units for sale increases is an example of how market power can be used to raise the final price.

The effect of the second key explanatory variable measuring the capacity of a production unit at the submitted price bid is assumed to vary across not only producers but also input types. Moreover, the producer- and type-specific slope parameter $\beta_{2}$ is expected to be negative because, as the theoretical predictions suggest, a significantly large production unit at stake moderates a producer's willingness to submit a price bid reflecting a higher markup. Thus, a producer faces the trade-off between bidding high to set a high price and bidding low to ensure that the production unit at stake is scheduled to produce electricity.

To take into account multiple seasonality effects, the regression model is enriched to include Day ${ }_{l t}$ and Season ${ }_{l t}$ variables. Day ${ }_{l t}$ are dummy variables that capture dayof-the-week effects. Non-working days represented by Saturdays, Sundays, and official public/bank holidays in England and Wales are taken as the base. Season ${ }_{l t}$ are dummy variables that capture annual seasonal effects. Finally, it is assumed that a disturbance term, $\varepsilon_{i j t}$, is orthogonal to the explanatory variables. 
Pooled OLS estimation of this regression model allows to analyze the development in the bidding behavior of electricity producers with respect to marginal and extramarginal production units and to evaluate the success of the reforms introduced by the regulatory authority to mitigate the exercise of market power and foster competition among electricity producers.

\subsubsection{Approximation of Marginal Costs}

The marginal costs of production units are approximated based on the definition of the thermal efficiency rate and data on quarterly input prices provided by the Department of Trade and Industry (1997-2002, January 1993 - December 2000). Before describing the methodology of approximating marginal costs, I first define the needed concepts used in energy economics.

Definition: The thermal efficiency rate is the efficiency rate with which heat energy contained in fuel is converted into electrical energy (Department of Trade and Industry, 1997-2002).

This definition allows us to express the thermal efficiency rate of production unit $X$ using input $Y$ to produce $1 \mathrm{MWh}$ of electricity denoted by $\kappa(X, Y)$ in the following way:

$$
\kappa(X, Y)=\frac{(1 \mathrm{MWh} \text { of electricity }) \cdot \text { factor } E}{\text { input } Y \cdot \text { factor } Y}
$$

where the additional terms denoted by factor $E$ and factor $Y$ are multipliers used to convert $1 \mathrm{MWh}$ of electricity and input $Y$ necessary to produce $1 \mathrm{MWh}$ of electricity into the commonly used energy measurement unit, for example, gigajoules (GJ). In particular, because $41.868 \mathrm{GJ}=11.63 \mathrm{MWh}$, it follows that factor $E=3.6 \mathrm{GJ} / \mathrm{MWh}$.

The formula for $\kappa(X, Y)$ suggests that the marginal cost of production unit $X$ using input $Y$ to produce $1 \mathrm{MWh}$ of electricity can be approximated by

$$
\begin{aligned}
M C(X, Y) & =(\text { price of input } Y) \cdot \text { input } Y= \\
& =(\text { price of input } Y) \cdot \frac{(1 \mathrm{MWh} \text { of electricity }) \cdot \text { factor } E}{\kappa(X, Y) \cdot \text { factor } Y} .
\end{aligned}
$$


If input prices are given in $£ / M W h$, then the above formula simplifies to

$$
M C(X, Y)=(\text { price of input } Y) \cdot \frac{(1 \mathrm{MWh} \text { of electricity })}{\kappa(X, Y)} .
$$

As summarized in Table B.5, there are seven types of production unit: coal, oil, nuclear, CCGT, OCGT, PSB, and hydro. Nuclear and hydro types of production unit are far from influencing the outcome of the uniform auction price because they mainly operate as the base-load and are located in the beginning of the supply schedule constructed by the market operator. This excludes the necessity to approximate their marginal costs. Combined cycle gas turbine (CCGT) and open cycle gas turbine (OCGT) production units are based on different technologies that use gas. The production units of pumped storage business (PSB) have turbines that pump water up to a hill-top reservoir during off-peak periods, which then allows the production of electricity during peak periods or during unexpected shortfalls in system supply. The marginal costs of these pumped facilities are approximated by the minimal price bid.

The efficiency rate of a production unit may also vary within an input type. The differences could be related to the age or size of a production unit. For an ex-post analysis, when approximating the marginal costs of marginal and extra-marginal production units that are the potential candidates to use to exercise market power, the unit-specific efficiency rates are used.

\subsection{Data}

The data consist of three data sets and cover the period January 1, 1995 - September 30, 2000. The first data set contains half-hourly market data for each trading period and includes observations on the System Marginal Price (SMP), the Pool Purchase Price (PPP), the Pool Selling Price (PSP), and the forecasted and actual demand for electricity. A summary of these data with the associated measurement units is provided in Table B.1. This data set also includes information about the production unit that set the System Marginal Price (SMP): the name of the production unit, its input type, and the name of the corresponding plant and electricity producer.

The second data set contains daily bid data for each trading day on the submitted start-up cost, no-load cost, three incremental price bids, and elbow points. This data set also includes information about the electricity producer, plant, and production unit 
for which the daily bids are submitted. A summary of these data with the associated measurement units is provided in Table B.2.

The third data set contains half-hourly bid data for each trading period on production capacity and price bids. This data set also includes information about the electricity producer, plant, and production unit for which the half-hourly bids are submitted. A summary of these data with the associated measurement units is provided in Table B.3.

Detailed information and my acknowledgments to people and organizations I was in contact with in the process of collecting data and materials will be listed at a later stage of the dissertation research.

Table B.4 describes the distribution of shares of production capacity and price setting among electricity producers between the financial years 1995/1996 and 1999/2000. To the original table reproduced from Bishop and McSorley (2001) I have added a measure of the Herfindahl-Hirschmann index computed as a sum of squared shares. The calculations show that the concentration measure decreased by almost twofold.

Figure C.1 describes in percentages the distribution of input types used for electricity production. In order to illustrate the compositional changes, I consider only the years 1990, 1995, and 2001. The necessary data for this figure are taken from the annual publications of the Department of Trade and Industry (1997-2002).

Figure C.2 describes the quarterly average input costs (measured in £/MWh) of electricity producers. The necessary data for this figure are taken from the monthly publications of the Department of Trade and Industry (January 1993 - December 2000). These average quarterly data on input costs are used in approximating the marginal costs of production units to analyze the development of the bidding behavior of electricity producers in relation to the introduced reforms during the liberalization process of the electricity supply industry in Great Britain.

\subsection{Results and Discussion}

In Section 3.3.3, the specification of the regression model to evaluate the success of the regulatory reforms has been introduced. The choice of a log-linear functional form of the regression model is based on the first-order condition from the expected profit maximization problem in a duopoly case as discussed in Section 3.3.2. Generally, loglinear regression models are often used in empirical research. One of the advantages of a log-linear regression model is that the estimated slope coefficients in this specification can be directly interpreted as elasticities. 
Based on economic intuition, the baseline regression model has been enriched to include trading day effects and annual seasonal effects. For the evaluation of the reforms introduced by the regulatory authority, I also include interaction terms with regime dummy variables. Figure 2.2 describes the creation of regime periods based on the dates when institutional changes and regulatory reforms took place. Data availability allows analyzing the development of the bidding behavior of electricity producers during 19952000. This therefore suggests analyzing the period January 1, 1995 - March 31, 1996 as the base or reference period.

The regression model is estimated using a pooled OLS procedure. Panel data techniques are not applicable because a producer's marginal or extra-marginal production units of a certain type need not be always the same across the highest-demand trading periods. For statistical inference I apply robust standard errors. This is justified as the null hypothesis about the equality of variances of residuals from the same model estimated, for example, during January 1, 1995 - March 31, 1996 and April 1, 1996 - June 22,1996 , is rejected at the $5 \%$ significance level.

The analysis includes National Power (NP), PowerGen (PG), TXU, Edison (Ed), British Energy (BE), and AES electricity producing companies, which are listed in Table B.4. Three electricity producers are excluded from the analysis: BNFL Magnox, EdF, and Scottish Interconnector. BNFL Magnox is excluded from the analysis because production units belonging to this producer were always infra-marginal and therefore far from influencing the market outcomes. EdF and Scottish Interconnector are producers that exported electricity into the England and Wales wholesale electricity market (see Figure 2.1). No data describing their technological characteristics are available, which does not allow approximating their marginal costs of producing electricity. Moreover, these exporters were not suspected of abusing market power. These circumstances limit the research on the analysis of electricity producers located in England and Wales. This is similar to Borenstein et al. (2002), who also restrict their research to measuring market inefficiencies in California's restructured wholesale electricity market by analyzing only electricity producers located in California.

Estimation results based on the period January 1, 1995 - September 30, 2000 are presented in the table below. These results describe the impact of the regulatory reforms on the bidding behavior of electricity producers. 
$\log \left(\right.$ Markup $\left._{i j t}\right)=\beta_{0 i}+\beta_{1 i} \cdot \log \left(\right.$ Production Units below Bid $\left.b_{i j t}\right)+\beta_{2 i j} \cdot \log \left(\right.$ Production Unit at Bid $\left.b_{i j t}\right)+$ $+\sum_{l=1}^{5} \gamma_{l} \cdot$ Day $_{l t}+\sum_{l=1}^{3} \theta_{l} \cdot$ Season $_{l t}+\varepsilon_{i j t}$

\begin{tabular}{|c|c|c|c|c|c|c|c|c|c|c|c|}
\hline \multicolumn{6}{|c|}{ Dependent Variable: $\log ($ Markup) } & \multicolumn{2}{|c|}{ Pre-Regime 4} & \multicolumn{2}{|c|}{ Regime 4} & \multicolumn{2}{|c|}{ Regime 5} \\
\hline \multicolumn{4}{|c|}{ Variable } & Coef. & Std. Err. & Coef. & Std. Err. & Coef. & Std. Err. & Coef. & Std. Err. \\
\hline \multirow{6}{*}{\multicolumn{3}{|c|}{ 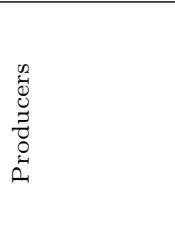 }} & NP & $6.110^{* * *}$ & 1.678 & $-17.517 * * *$ & 2.712 & $-10.725 * * *$ & 1.713 & -1.767 & 1.687 \\
\hline & & & $\mathrm{PG}$ & -0.409 & 1.358 & $7.216^{* * *}$ & 2.425 & 1.529 & 1.419 & 2.244 & 1.480 \\
\hline & & & $\mathrm{TXU}$ & $2.491 * * *$ & 0.195 & & & & & $0.045 * * *$ & 0.017 \\
\hline & & & Ed & $1.844^{* * *}$ & 0.217 & $0.758^{* *}$ & 0.386 & 0.076 & 0.274 & $-1.350 * * *$ & 0.277 \\
\hline & & & $\mathrm{BE}$ & 0.648 & 1.605 & & & & & & \\
\hline & & & AES & $5.904^{* * *}$ & 0.078 & & & & & $0.880^{* * *}$ & 0.047 \\
\hline \multirow{6}{*}{ 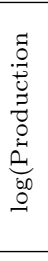 } & \multirow{6}{*}{\multicolumn{2}{|c|}{ 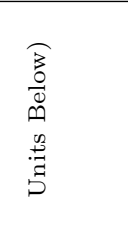 }} & $\mathrm{NP}$ & 0.034 & 0.162 & $1.381^{* * *}$ & 0.278 & $0.722 * * *$ & 0.166 & 0.096 & 0.164 \\
\hline & & & $\mathrm{PG}$ & 0.141 & 0.106 & 0.096 & 0.179 & $0.298^{* * *}$ & 0.113 & 0.109 & 0.110 \\
\hline & & & TXU & 0.022 & 0.014 & & & & & & \\
\hline & & & $\mathrm{Ed}$ & $0.033^{* * *}$ & 0.003 & $-0.038^{* * *}$ & 0.004 & -0.004 & 0.003 & $-0.024 * * *$ & 0.009 \\
\hline & & & $\mathrm{BE}$ & $0.497^{* * *}$ & 0.192 & & & & & & \\
\hline & & & AES & $-0.039 * * *$ & 0.003 & & & & & & \\
\hline \multirow{17}{*}{ 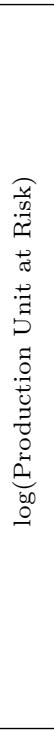 } & & & Coal & $-0.766^{* * *}$ & 0.101 & $1.118^{* * *}$ & 0.152 & $0.964 * * *$ & 0.106 & $0.334^{* * *}$ & 0.108 \\
\hline & & 号 & Oil & $-0.589 * * *$ & 0.091 & $1.057 * * *$ & 0.137 & $0.887 * * *$ & 0.095 & $0.295 * * *$ & 0.098 \\
\hline & & Z & CCGT & $0.301^{* * *}$ & 0.073 & & & & & & \\
\hline & & & OCGT & $-0.521 * * *$ & 0.145 & $1.428 * * *$ & 0.222 & $1.198^{* * *}$ & 0.152 & 0.247 & 0.161 \\
\hline & & & Coal & $0.297 * *$ & 0.140 & $-1.462 * * *$ & 0.229 & $-0.645 * * *$ & 0.151 & $-0.471 * * *$ & 0.169 \\
\hline & & L & Oil & $0.402 * * *$ & 0.123 & $-1.237 * * *$ & 0.199 & $-0.609 * * *$ & 0.133 & $-0.424 * * *$ & 0.151 \\
\hline & & & OCGT & $1.068^{* * *}$ & 0.204 & $-2.329 * * *$ & 0.329 & $-1.206 * * *$ & 0.222 & $-0.916 * * *$ & 0.251 \\
\hline & & $p$ & Coal & $-0.053 *$ & 0.029 & & & & & & \\
\hline & & 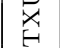 & CCGT & $0.125 * *$ & 0.052 & & & & & & \\
\hline & & & OCGT & $0.501 * * *$ & 0.061 & & & & & & \\
\hline & & & Coal & $0.409 * * *$ & 0.032 & & & & & & \\
\hline & & 茥 & OCGT & $1.869^{* * *}$ & 0.080 & & & & & & \\
\hline & & & PSB & $0.234 * * *$ & 0.045 & -0.118 & 0.080 & 0.026 & 0.057 & $0.308^{* * *}$ & 0.057 \\
\hline & & 程 & Coal & $-0.357^{* * *}$ & 0.081 & & & & & & \\
\hline & & Un & Coal & $-0.680 * * *$ & 0.013 & & & & & & \\
\hline & & 焉 & CCGT & $-0.781 * * *$ & 0.073 & & & & & & \\
\hline & & & OCGT & $-0.714^{* * *}$ & 0.018 & & & & & & \\
\hline \multirow{5}{*}{\multicolumn{3}{|c|}{ 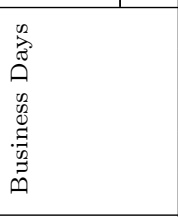 }} & Mo & $0.083^{* * *}$ & 0.011 & & & & & & \\
\hline & & & $\mathrm{Tu}$ & $0.081 * * *$ & 0.011 & & & & & & \\
\hline & & & We & $0.083^{* * *}$ & 0.011 & & & & & & \\
\hline & & & Th & $0.074 * * *$ & 0.011 & & & & & & \\
\hline & & & $\mathrm{Fr}$ & $0.058 * * *$ & 0.011 & & & & & & \\
\hline \multirow{3}{*}{ 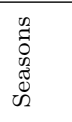 } & & & Spring & $0.019 * *$ & 0.009 & & & & & & \\
\hline & & & Summer & $-0.026 * * *$ & 0.009 & & & & & & \\
\hline & & & Autumn & $0.018^{* *}$ & 0.009 & & & & & & \\
\hline
\end{tabular}

Notes: A markup is measured as a price bid minus approximated marginal cost. In some cases the difference was negative. In order to account for the possibility of a measurement error resulting from the approximation of marginal costs, I add $£ 5$, as was done in Wolfram (1998). The last three columns contain coefficient estimates for interaction terms with regime dummy variables. *, **, and *** stand for the $10 \%, 5 \%$, and $1 \%$ significance levels, respectively. Adj. $\mathrm{R}^{2}=0.751$ and Obs. $=17,546$. 
January 1, 1995 - March 31, 1996 represents the base period. For the later periods I assume that the intercept term and slope parameters in front of the key explanatory variables can vary. The validity of this assumption is verifiable by the formal testing. For example, a test for the equality of the intercept term for NP during Jan 95 - Mar 96 and Pre-Regime 4 can be represented as testing the following null hypothesis:

$$
\mathrm{H}_{0}: \beta_{0, \mathrm{NP}}^{\text {Pre-Regime } 4}-\beta_{0, \mathrm{NP}}^{\mathrm{Jan} 95-\mathrm{Mar} 96}=\delta_{0, \mathrm{NP}}^{\text {Pre-Regime } 4}=0
$$

The value of $t_{\text {stat }} \approx-6.459$ suggests rejecting $\mathrm{H}_{0}$ at the $1 \%$ significance level.

The estimation results allow one to draw conclusions related to the analysis of the theoretical predictions and of the success of the regulatory reforms. For illustration purposes I summarize in graphs the estimation results for the incumbent producers, which are based on the highest-demand trading periods during different regimes.

The theoretical predictions indicate that when a larger capacity of production units is available, there is an incentive to exercise market power. As described in Figure 3.4, the incumbents' incentives to submit price bids in excess of marginal costs when a larger capacity of production units below (the solid line) is greater during the subsequent regime periods than during the reference period, January 1, 1995 - March 31, 1996.

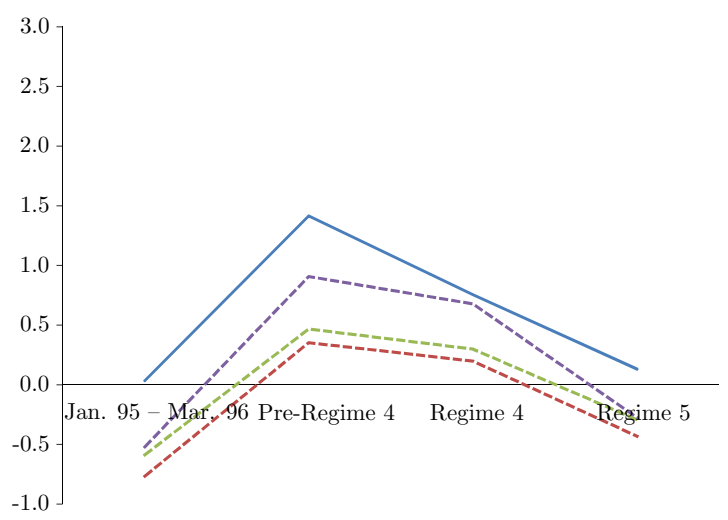

(a) Estimation Results for NP

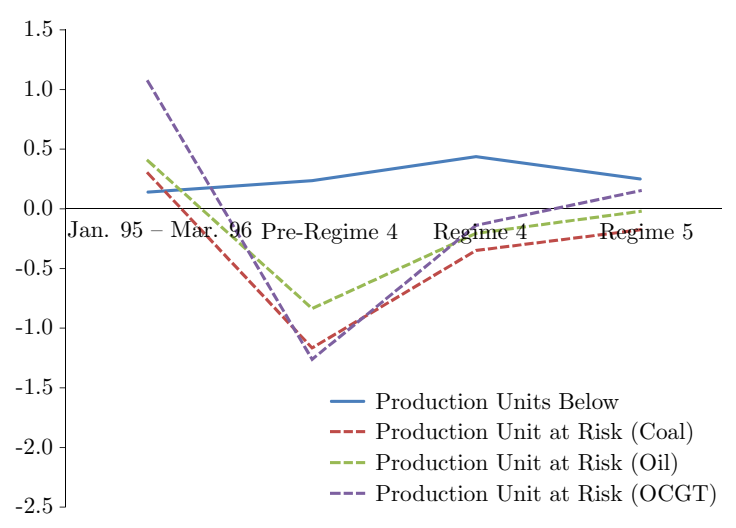

(b) Estimation Results for PG

Source: Author's calculations.

Figure 3.4: Do Estimation Results Conform to Theoretical Predictions? Analysis of $\hat{\beta}_{1}$ and $\hat{\beta}_{2 j}$ for the Incumbent Producers

The incentive to submit a price bid reflecting a high markup is however moderated by the presence of the risk that the production unit at stake may not be scheduled to 
produce electricity. This effect also generally need not be the same across producers. Moreover, if a single producer has several types of production unit, then this disincentive may additionally vary across types of production unit. The detailed modeling of the second level of asymmetry produced significantly better estimation results in contrast to the case when symmetry was assumed. The asymmetry at the producer and input-type levels is usually referred to as inter- and intra-firm differences.

Estimation results summarized in Figure 3.4 indicate that during the reference period, January 1995 - March 1996, the attitude towards the risk of losing a production unit when a high price bid is submitted (the dashed lines) are confirmed only for NP (the larger incumbent producer), whereas estimation results contradictory to the theoretical predictions are obtained for PG (the smaller incumbent producer). This counter-intuitive attitude towards the risk observed during the base period could resemble the aggressive bidding behavior possibly caused by the small overall influence of the second incumbent producer to exercise market power (a small intercept term for PG illustrated in Figure 3.5).

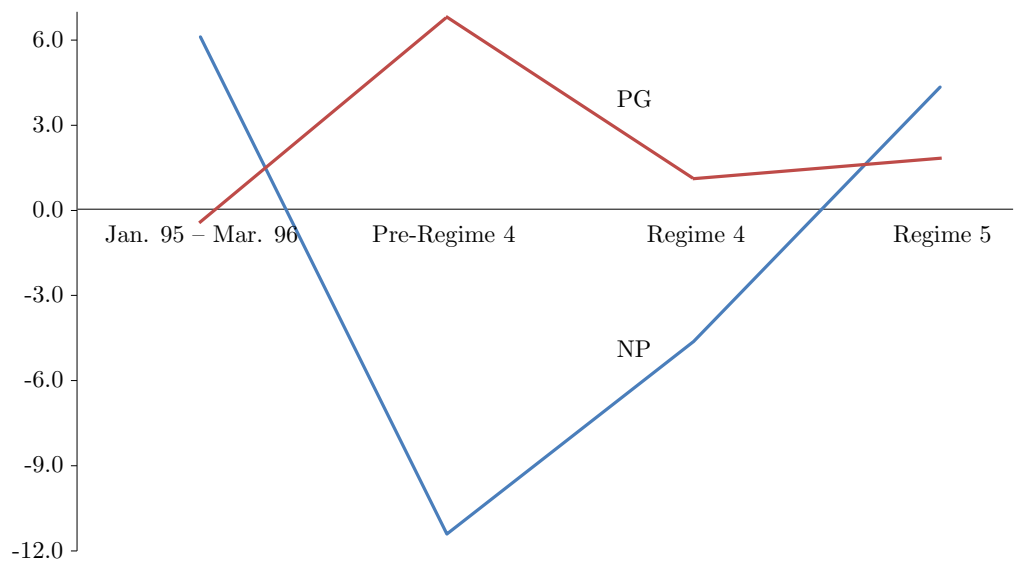

Source: Author's calculations.

Figure 3.5: Is NP or PG More Influential? Analysis of $\hat{\beta}_{0}$ for the Incumbent Producers

An interesting observation for NP described in Figure 3.4 and Figure 3.5 is related to the Pre-Regime 4 and Regime 4 periods. The large decrease in NP's overall influence to exercise market power described in Figure 3.5 (a significantly decreased intercept term for NP during the Pre-Regime 4 and Regime 4 periods compared to the reference period) possibly caused a change in the attitude towards the risk described in Figure 3.4. Namely during the Pre-Regime 4 and Regime 4 periods, NP manifested aggressive bidding behavior similar to PG during the reference period. The issue of aggressive bidding in 
the wholesale electricity market in England and Wales is also mentioned in Bergman et al. (1999). Conversely, as described in Figure 3.4, during the subsequent regime periods, the attitude of PG towards the risk of losing a production unit at stake conforms to theoretical predictions.

As described in Figure 3.4, during the last regime period all theoretical predictions describing the incentives and disincentives of NP and PG to exercise market power are confirmed by the empirical results (the only exception is related to PG's OCGT production facilities). This can partly be attributed to the success of the regulatory reforms at disciplining the bidding behavior of electricity producers.

As the intercept term for NP described in Figure 3.5 significantly decreased, we can infer that the overall influence of NP to exercise market power reduced during the subsequent regime periods. Moreover, as described in Figure 3.6, during the last two regime periods, the net incentives to exercise market power uniformly decreased, thereby shedding light on the successes of the regulatory reforms at mitigating the noncompetitive bidding behavior of the larger incumbent producer.

For PG, as summarized in Figure 3.6, because during the subsequent regime periods disincentives to exercise market power always uniformly dominated (negative net incentives), we can conclude that the reforms were successful, too. Hence, PG in general also became less optimistic about exercising market power.

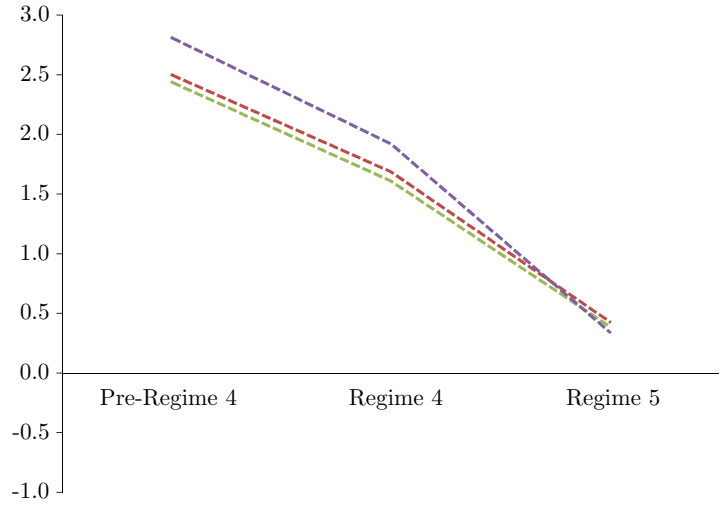

(a) Incentives vs. Disincentives for NP

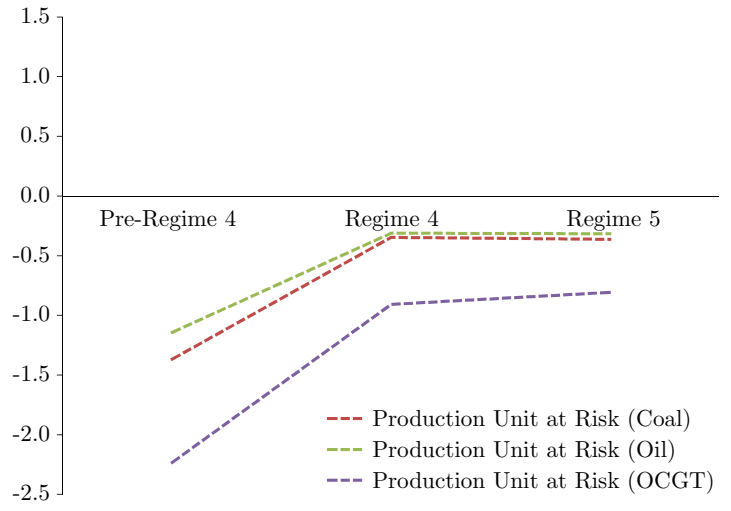

(b) Incentives vs. Disincentives for PG

Source: Author's calculations.

Figure 3.6: Net Incentive Analysis for the Incumbent Producers. Analysis of $\hat{\delta}_{1}+\hat{\delta}_{2 j}$

The estimation results suggest that the bidding behavior of British Energy and AES are generally in line with theoretical predictions, whereas the bidding behavior of Edison 
and TXU only partly conform to the theoretical predictions. The latter could be related to the possibility that Edison and TXU (these producers received a large portion of the divested plants) were in the phase of learning.

Dummy variables reflecting day-of-the-week effects also confirm economic intuition that the extent of an exercise of market power during different trading days need not be the same. In particular, the largest and the smallest estimated coefficients correspond to Monday and Friday trading days, respectively. Overall, the estimated model is able to explain about $75 \%$ of the variations in the dependent variable by the variations in the key explanatory variables augmented by the trading day and annual seasonal effects.

For the robustness check, I consider the second-fifth highest-demand trading periods with nominal and real price markups. Complete estimation results are presented in Appendix D. Compared to the estimation results for the first highest-demand trading periods, in some instances there are sign reversals in the estimated parameters but they are statistically insignificant. In general, qualitative conclusions regarding the analysis of the theoretical predictions and the evaluation of the regulatory reforms are similar to those for the first highest-demand trading periods. The results are therefore generally robust.

\subsection{Conclusions}

In this paper I analyzed the bidding behavior of electricity producers to evaluate the success of the regulatory reforms introduced during the liberalization process of the electricity supply industry in Great Britain. New results are obtained that indicate the success of regulatory reforms at mitigating an exercise of market power of the incumbent electricity producers.

In particular, as the findings indicate, the overall influence of National Power to exercise market power was decreased to a large extent, which however brought about aggressive bidding behavior with respect to the production unit at risk. This counter-intuitive observation finally disappeared and all theoretical predictions are confirmed during the last regime period. Moreover, net incentives to exercise market power uniformly decreased in later regime periods.

During the later regime periods theoretical predictions reflecting incentives and disincentives of PowerGen to exercise market power are confirmed by the empirical results. An interesting finding is that during the subsequent regime periods the disincentive to exercise market power always uniformly dominated over the incentive. 
In addition to the analysis of the bidding behavior of electricity producers during the highest-demand trading periods (as was done, for example, in Crawford et al., 2007), I also analyze the bidding behavior of electricity producers during the next four highestdemand trading periods with nominal and real price markups. The results generally conform to those of the first highest-demand trading periods but with infrequent sign reversals for the variables which are statistically insignificant.

The findings and conclusions of this research could be of interest to countries that formed or are about to form the operation of their electricity supply industry based on the model of the England and Wales wholesale electricity market. 


\section{References}

Anderson, E. J. and H. Xu, "Nash Equilibria in Electricity Markets with Discrete Prices," Mathematical Methods of Operations Research, 2004, 60 (2), 215-238.

Bergman, L., C. Doyle, J. Gual, L. Hultkrantz, D. Neven, L.-H. Röller, and L. Waverman, Europe's Network Industries: Conflicting Priorities - Telecommunications, Vol. 1 of Monitoring European Deregulation, London, UK: Center for Economic Policy Research, 1998.

_ , G. Brunekreeft, C. Doyle, N.-H. M. von der Fehr, D. M. Newbery, M. Pollitt, and P. Régibeau, A European Market for Electricity?, Vol. 2 of Monitoring European Deregulation, London, UK: Center for Economic Policy Research, 1999.

Bishop, S. and C. McSorley, "Regulating Electricity Markets: Experience from the United Kingdom," The Electricity Journal, 2001, 14 (10), 81-86.

Borenstein, S., J. B. Bushnell, and F. A. Wolak, "Measuring Market Inefficiencies in California's Restructured Wholesale Electricity Market," The American Economic Review, 2002, 92 (5), 1376-1405.

Bower, J., "Why Did Electricity Prices Fall in England and Wales? Market Mechanism or Market Structure," The Oxford Institute for Energy Studies, EL 02, 2002, pp. 1-58.

Crawford, G. S., J. Crespo, and H. Tauchen, "Bidding Asymmetries in Multi-Unit Auctions: Implications of Bid Function Equilibria in the British Spot Market for Electricity," International Journal of Industrial Organization, 2007, 25 (6), 1233-1268.

Department of Trade and Industry, Digest of United Kingdom Energy Statistics, London, UK: The Stationery Office, 1997-2002.

_ , Energy Trends, London, UK: The Stationery Office, January 1993 - December 2000.

Edwards, D. W., Energy Trading and Investing: Trading, Risk Management and Structuring Deals in the Energy Market, New York, USA: McGraw-Hill, 2010.

Electricity Pool, "Pooling and Settlement Agreement for the Electricity Industry in England and Wales," 1990.

Geradin, D., "Twenty Years of Liberalization of Network Industries in the European Union: Where Do We Go Now?," Tilburg University, Mimeo, 2006, pp. 1-19.

Green, R. J. and D. M. Newbery, "Competition in the British Electricity Spot Market," Journal of Political Economy, 1992, 100 (5), 929-953.

Griffin, J. M., A Smart Energy Policy: An Economist's Rx for Balancing Cheap, Clean, and Secure Energy Business \& Economics, New Haven, USA: Yale University Press, 2009.

Intenational Energy Agency, Key World Energy Statistics, Paris, France: OECD/IEA, various years. 
Joskow, P. L., "Foreword: US vs. EU Electricity Reforms Achievement," in J.-M. Glachant and F. Lévêque, eds., Electricity Reform in Europe, Cheltenham, UK: Edward Elgar Publishing Limited, 2009.

Mount, T., "Market Power and Price Volatility in Restructured Markets for Electricity," Decision Support Systems, 2001, 30 (3), 311-325.

National Grid Company, Seven Year Statement, London, UK: National Grid Company, 1994-2001.

Newbery, D. M., "The UK Experience: Privatization with Market Power," University of Cambridge, Mimeo, 1999, pp. 1-23.

Robinson, T. and A. Baniak, "The Volatility of Prices in the English and Welsh Electricity Pool," Applied Economics, 2002, 34 (12), 1487-1495.

Smil, V., Energy, Oxford, UK: Oneworld Publications, 2006.

Sweeting, A., "Market Power in the England and Wales Wholesale Electricity Market 19952000," The Economic Journal, 2007, 117 (520), 654-685.

Von der Fehr, N.-H. M. and D. Harbord, "Spot Market Competition in the UK Electricity Industry," The Economic Journal, 1993, 103 (418), 531-546.

Wolak, F. A., "Market Design and Price Behavior in Restructured Electricity Markets: An International Comparison," Deregulation and Interdependence in the Asia-Pacific Region, NBER-EASE, 2000, 8, 79-137.

- and R. H. Patrick, "The Impact of Market Rules and Market Structure on the Price Determination Process in the England and Wales Electricity Market," NBER Working Paper No. W8248, 2001, pp. 1-86.

Wolfram, C. D., "Strategic Bidding in a Multiunit Auction: An Empirical Analysis of Bids to Supply Electricity in England and Wales," The RAND Journal of Economics, 1998, 29 (4), 703-725.

_ , "Measuring Duopoly Power in the British Electricity Spot Market," The American Economic Review, 1999, 89 (4), 805-826.

Zemin, J., Research on Energy Issues in China, Shanghai, China: Shanghai Jiao Tong University Press, 2008. 


\section{Appendices}

\section{A Global Outlook of Energy}

Energy forms the lifeblood of a growing and healthy economy. In this respect, there are three goals for energy use: cheapness, cleanliness, and security. These goals however share conflicting priorities whose optimal resolution becomes significant not only for economic welfare but also for environmental and even political aspects. For example, coal, on the one hand, may seem to be cheap and secure, but it is certainly not clean. Nuclear energy, on the other hand, is certainly not cheap and also raises concerns about cleanliness and especially security (Griffin, 2009). Nevertheless, the development of nuclear energy is very important in the face of the fact that with world energy consumption increasing at a rate of about $5 \%$ p.a., reserves of all fossil fuels are expected to run out in one or two centuries. In particular, the success of nuclear fusion research experiments is expected to provide electricity production for human use for over 100 million years, which is crucial given that electricity consumption accounts for the lion's share of energy use in different areas of the economy (Zemin, 2008).

In Figures A.1-A.2, I present a global view of electricity production and consumption. In particular, Figure A.1 depicts electricity production in China, Japan, Russia, the UK, the USA, and the world during 1900-2000 (Smil, 2006). This figure illustrates the presence of structural breaks in the growth rates of electricity production, which were possibly caused by the world wars and economic depression.

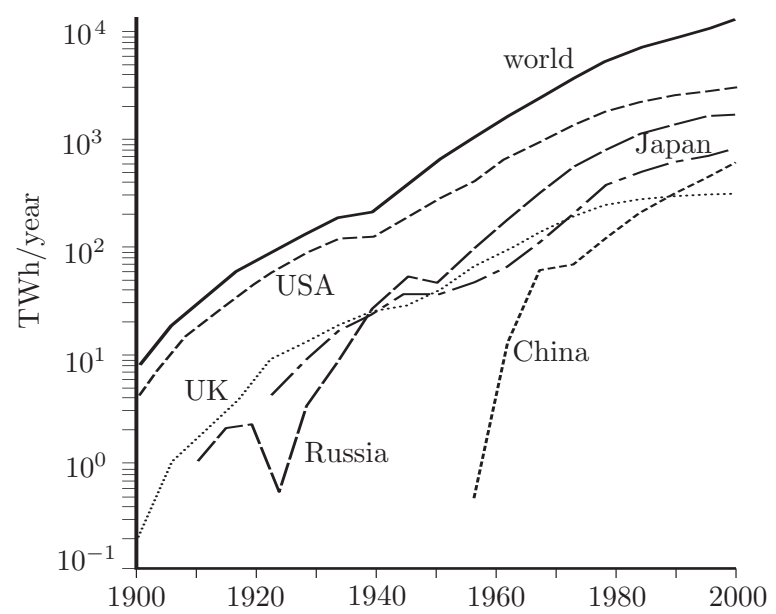

Source: Smil (2006).

Figure A.1: Electricity Production: Global Outlook 
In Figure A.2(a), I construct the Lorenz curve for the year 2004 based on a sample of 136 countries. Data on population and electricity consumption (the latter is defined as gross production + imports - exports - transmission/distribution losses) are taken from Intenational Energy Agency (various years). For the construction of the Lorenz curve I also use data from http://www.photius.com to order countries based on GDP per capita as of January 2005.

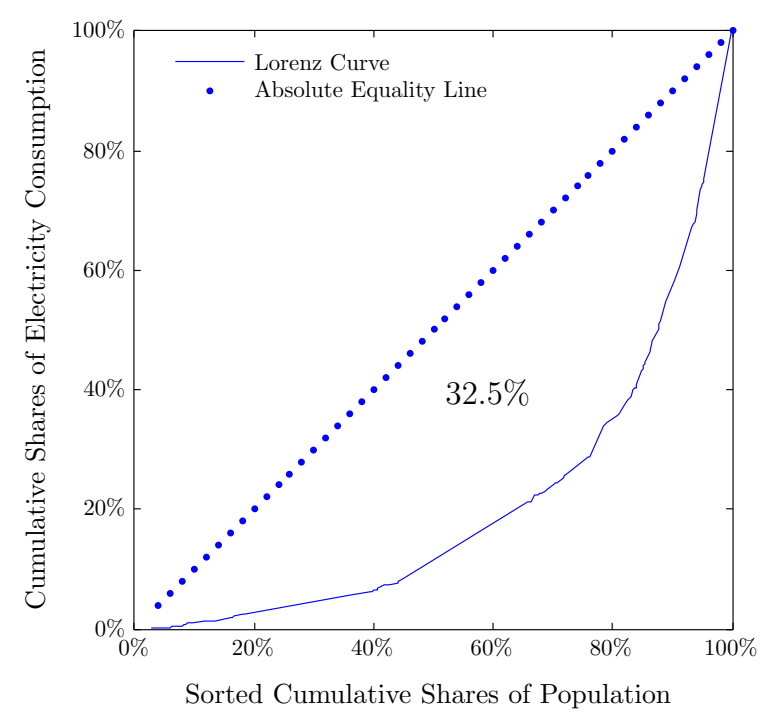

(a) Electricity Consumption in 2004

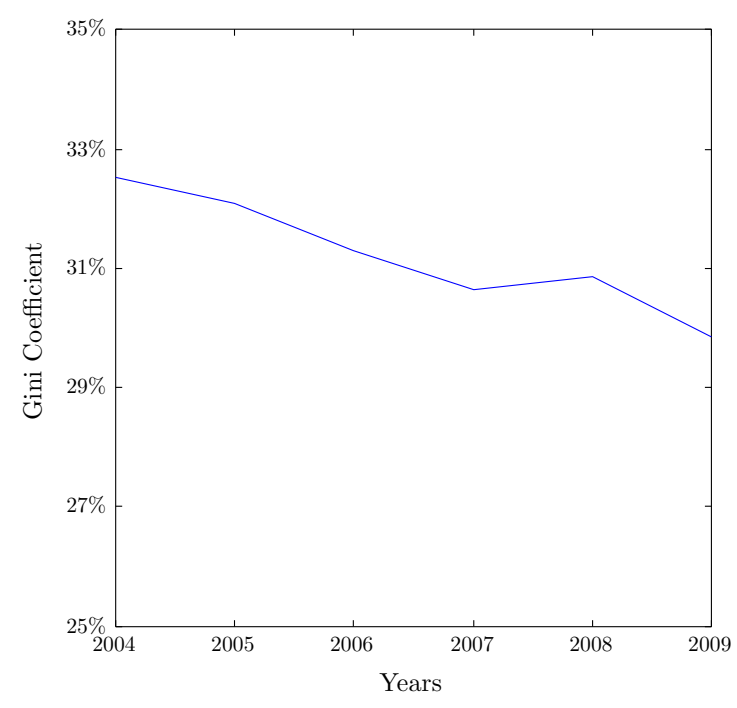

(b) Gini Coefficient during 2004-2009

Sources: Intenational Energy Agency (various years); author's calculations.

Figure A.2: Electricity Consumption: Global Outlook

The constructed Lorenz curve in Figure A.2(a) depicts the relationship between the sorted cumulative shares of population and the respective cumulative shares of electricity consumption. The analysis indicates that in the year 2004, about $35 \%$ of total electricity consumption was shared by $80 \%$ of the total population considered in the sample. Numerical integration yields the Gini coefficient approximately equal to 0.325. These findings suggest the presence of significant disparities in electricity consumption among the selected countries of the world. As presented in Figure A.2(b), it is interesting to note that the disparities in electricity consumption have decreased in recent years. 


\section{B Tables}

Table B.1: Market Data (January 2000)

\begin{tabular}{lccccc}
\hline & SMP & PPP & PSP & Forecasted Demand & $\begin{array}{c}\text { Actual Demand } \\
(\text { MW })\end{array}$ \\
\hline Mean & 24.39 & 30.96 & 32.10 & $38,464.60$ & $38,615.42$ \\
Min & 8.00 & 8.00 & 8.00 & $25,001.00$ & $22,988.70$ \\
Max & 77.89 & 320.35 & 359.01 & $49,945.00$ & $49,617.08$ \\
Std. Dev. & 12.54 & 37.24 & 41.91 & $5,247.83$ & $5,559.35$ \\
\hline Frequency & 30 min & 30 min & 30 min & 30 min & 30 min \\
Obs. & 1,488 & 1,488 & 1,488 & 1,488 & 1,488 \\
\hline
\end{tabular}

Source: Data set 1 described in Section 3.4; author's calculations.

Table B.2: Daily Bid Data at the Level of Production Unit (January 2000)

\begin{tabular}{|c|c|c|c|c|c|c|c|}
\hline & $\begin{array}{c}\text { Start-Up } \\
(£)\end{array}$ & $\begin{array}{c}\text { No-Load } \\
(£ / h)\end{array}$ & $\begin{array}{c}\text { Inc } 1 \\
(£ / \mathrm{MWh})\end{array}$ & $\begin{array}{c}\text { Inc 2 } \\
(£ / \mathrm{MWh})\end{array}$ & $\begin{array}{c}\text { Inc 3 } \\
(£ / \mathrm{MWh})\end{array}$ & $\begin{array}{l}\text { Elb 1 } \\
(\mathrm{MW})\end{array}$ & $\begin{array}{l}\text { Elb 2 } \\
\text { (MW) }\end{array}$ \\
\hline Mean & $13,100.45$ & $1,938.69$ & 164.09 & 171.46 & 172.06 & $7,978.40$ & $9,757.51$ \\
\hline Min & 0.00 & 0.00 & 0.00 & 0.00 & 0.00 & 55.00 & 181.00 \\
\hline Max & $99,999.00$ & $9,999.99$ & 999.99 & 999.99 & 999.99 & $9,999.00$ & $9,999.00$ \\
\hline Std. Dev. & $28,419.23$ & $3,081.44$ & 328.42 & 325.45 & 325.24 & $3,917.77$ & $1,496.45$ \\
\hline Frequency & Daily & Daily & Daily & Daily & Daily & Daily & Daily \\
\hline Obs. & 8,587 & 8,587 & 8,587 & 8,587 & 8,587 & 8,587 & 8,587 \\
\hline
\end{tabular}

Source: Data set 2 described in Section 3.4; author's calculations.

Table B.3: Half-Hourly Bid Data at the Level of Production Unit (January 2000)

\begin{tabular}{lcc}
\hline & $\begin{array}{c}\text { Production Capacity } \\
(\mathrm{MW})\end{array}$ & $\begin{array}{c}\text { Price Bid } \\
(£ / \mathrm{MWh})\end{array}$ \\
\hline Mean & 87.70 & 39.54 \\
Min & 0.00 & 0.00 \\
Max & 494.50 & $37,865.50$ \\
Std. Dev. & 124.06 & 106.68 \\
\hline Frequency & $30 \mathrm{~min}$ & $30 \mathrm{~min}$ \\
Obs. & 450,336 & 450,336 \\
\hline
\end{tabular}

Source: Data set 3 described in Section 3.4; author's calculations. 
Table B.4: Structural Impact of National Power and PowerGen Divestments

\begin{tabular}{rlrrrr}
\hline & & \multicolumn{2}{c}{ Share of Capacity } & \multicolumn{2}{c}{ Share of Price Setting } \\
& & $1995 / 1996$ & $1999 / 2000$ & $1995 / 1996$ & $1999 / 2000$ \\
\hline 1 & National Power & 33.7 & 13.0 & 44.8 & 14.6 \\
2 & PowerGen & 28.1 & 16.5 & 31.8 & 16.8 \\
3 & BNFL Magnox & 5.8 & 5.4 & 0.0 & 0.0 \\
4 & EdF & 3.3 & 3.3 & 0.7 & 10.7 \\
5 & Scottish Interconnector & 2.3 & 2.2 & 1.7 & 0.4 \\
6 & TXU & 1.6 & 9.2 & 7.3 & 11.8 \\
7 & Edison & 3.8 & 8.9 & 0.0 & 21.1 \\
8 & British Energy & 12.0 & 14.8 & 0.0 & 19.9 \\
9 & AES & 0.5 & 7.6 & 0.5 & 0.4 \\
10 & Combined cycle gas turbines & 7.8 & 17.2 & 0.0 & 0.0 \\
11 & Others & 1.3 & 2.0 & 0.33 & 0.16 \\
\hline
\end{tabular}

Source: Reproduced from Bishop and McSorley (2001).

Note: $\mathrm{HHI}=$ Herfindahl-Hirschmann Index (sum of squared shares: monopoly $=1$ ).

Table B.5: Distribution of Types of Production Unit

\begin{tabular}{|c|c|c|c|c|c|c|c|c|c|}
\hline & \multirow[t]{2}{*}{ Producer } & \multicolumn{7}{|c|}{ Types of Production Unit } & \multirow[b]{2}{*}{ Subtotal } \\
\hline & & Coal & Oil & Nuclear & CCGT & OCGT & PSB & Hydro & \\
\hline 1 & National Power & 58 & 11 & 0 & 6 & 48 & 0 & 4 & 127 \\
\hline 2 & PowerGen & 28 & 9 & 0 & 9 & 17 & 0 & 4 & 67 \\
\hline 3 & BNFL Magnox & 0 & 0 & 40 & 0 & 0 & 0 & 1 & 41 \\
\hline 6 & TXU & 16 & 0 & 0 & 2 & 8 & 0 & 0 & 26 \\
\hline 7 & Edison & 8 & 0 & 0 & 0 & 4 & 10 & 0 & 22 \\
\hline 8 & British Energy & 4 & 0 & 10 & 0 & 0 & 0 & 0 & 14 \\
\hline \multirow[t]{2}{*}{9} & AES & 9 & 0 & 0 & 1 & 4 & 0 & 0 & 14 \\
\hline & Subtotal & 123 & 20 & 50 & 18 & 81 & 10 & 9 & 311 \\
\hline
\end{tabular}

Source: National Grid Company (1994-2001) publications for various years; author's calculations. 


\section{Figures}

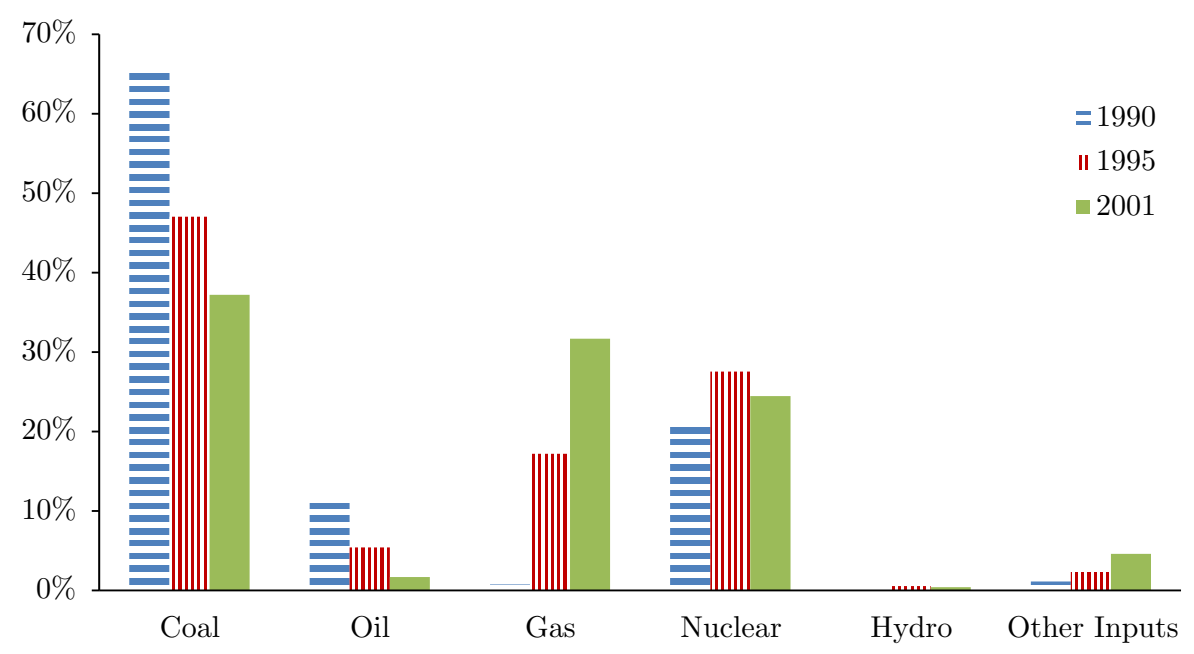

Source: Department of Trade and Industry (1997-2002); author's calculations.

Figure C.1: Distribution of Input Types for Electricity Production

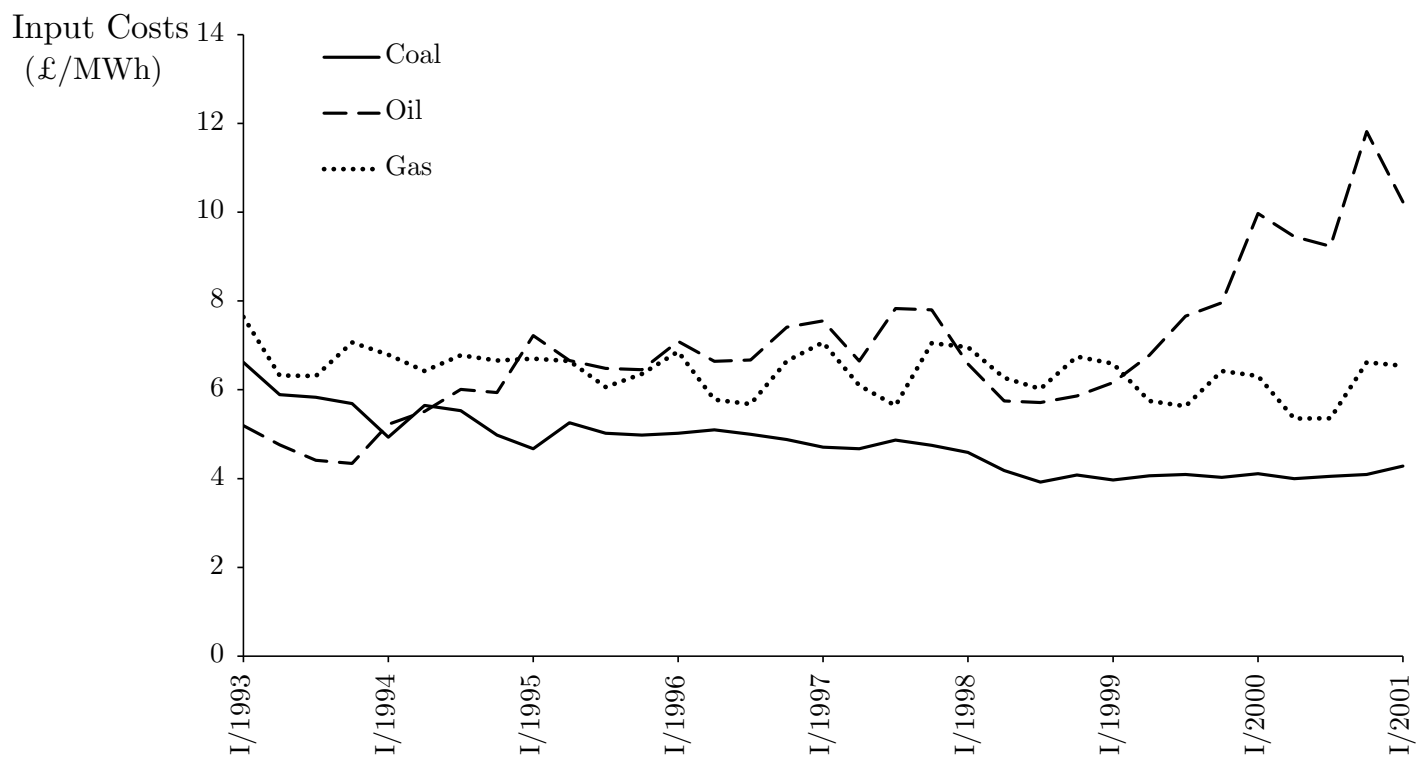

Source: Department of Trade and Industry (January 1993 - December 2000); author's calculations.

Figure C.2: Quarterly Average Input Costs of Electricity Producers in the UK 


\section{Estimation Tables}

Table D.1: Estimation Results Based on the First Highest-Demand Trading Period

\begin{tabular}{|c|c|c|c|c|c|c|c|c|c|c|c|}
\hline \multicolumn{6}{|c|}{ Dependent Variable: log(Real Markup) } & \multicolumn{2}{|c|}{ Pre-Regime 4} & \multicolumn{2}{|c|}{ Regime 4} & \multicolumn{2}{|c|}{ Regime 5} \\
\hline \multicolumn{4}{|c|}{ Variable } & Coef. & Std. Err. & Coef. & Std. Err. & Coef. & Std. Err. & Coef. & Std. Err. \\
\hline \multirow{6}{*}{\multicolumn{3}{|c|}{ 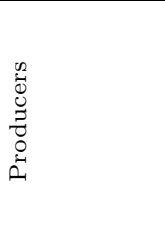 }} & NP & $7.007^{* * *}$ & 1.688 & $-18.348^{* * *}$ & 2.691 & $-10.615^{* * *}$ & 1.724 & -1.960 & 1.698 \\
\hline & & & $\mathrm{PG}$ & 0.277 & 1.358 & $6.594 * * *$ & 2.456 & 2.013 & 1.425 & $2.479 *$ & 1.488 \\
\hline & & & $\mathrm{TXU}$ & $2.623 * * *$ & 0.187 & & & & & $0.085 * * *$ & 0.018 \\
\hline & & & $\mathrm{Ed}$ & $1.938 * * *$ & 0.209 & $0.813 * *$ & 0.385 & 0.063 & 0.268 & $-1.233 * * *$ & 0.268 \\
\hline & & & $\mathrm{BE}$ & $2.749^{*}$ & 1.541 & & & & & & \\
\hline & & & AES & $6.152^{* * *}$ & 0.082 & & & & & $0.898 * * *$ & 0.049 \\
\hline \multirow{6}{*}{ 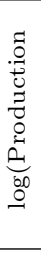 } & \multirow{6}{*}{\multicolumn{2}{|c|}{ 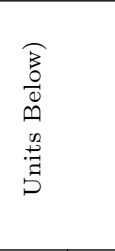 }} & NP & -0.068 & 0.163 & $1.491 * * *$ & 0.276 & $0.727 * * *$ & 0.167 & 0.132 & 0.165 \\
\hline & & & $P G$ & 0.075 & 0.107 & 0.166 & 0.181 & $0.255 * *$ & 0.114 & 0.086 & 0.111 \\
\hline & & & $\mathrm{TXU}$ & $0.022^{*}$ & 0.012 & & & & & & \\
\hline & & & $\mathrm{Ed}$ & $0.034^{* * *}$ & 0.003 & $-0.040 * * *$ & 0.004 & $-0.007^{* *}$ & 0.003 & $-0.029 * * *$ & 0.009 \\
\hline & & & $\mathrm{BE}$ & $0.342 *$ & 0.183 & & & & & & \\
\hline & & & AES & $-0.038 * * *$ & 0.004 & & & & & & \\
\hline \multirow{17}{*}{ 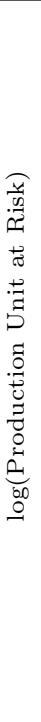 } & & & Coal & $-0.755 * * *$ & 0.101 & $1.103 * * *$ & 0.150 & $0.946 * * *$ & 0.106 & $0.321 * * *$ & 0.108 \\
\hline & & n & Oil & $-0.578 * * *$ & 0.091 & $1.042^{* * *}$ & 0.135 & $0.873 * * *$ & 0.095 & $0.286 * * *$ & 0.098 \\
\hline & & 乙 & CCGT & $0.295 * * *$ & 0.071 & & & & & & \\
\hline & & & OCGT & $-0.501 * * *$ & 0.145 & $1.401 * * *$ & 0.220 & $1.174 * * *$ & 0.152 & 0.234 & 0.162 \\
\hline & & & Coal & $0.285^{* *}$ & 0.140 & $-1.447 * * *$ & 0.231 & $-0.657 * * *$ & 0.151 & $-0.464 * * *$ & 0.170 \\
\hline & & L & Oil & $0.391 * * *$ & 0.122 & $-1.224 * * *$ & 0.201 & $-0.616^{* * *}$ & 0.134 & $-0.414^{* * *}$ & 0.153 \\
\hline & & & OCGT & $1.052^{* * *}$ & 0.203 & $-2.307 * * *$ & 0.331 & $-1.216 * * *$ & 0.223 & $-0.898 * * *$ & 0.253 \\
\hline & & 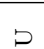 & Coal & $-0.049 *$ & 0.029 & & & & & & \\
\hline & & $\stackrel{x}{H}$ & CCGT & $0.113^{* *}$ & 0.047 & & & & & & \\
\hline & & & OCGT & $0.508 * * *$ & 0.060 & & & & & & \\
\hline & & & Coal & $0.412^{* * *}$ & 0.031 & & & & & & \\
\hline & & 可 & OCGT & $1.874^{* * *}$ & 0.079 & & & & & & \\
\hline & & & PSB & $0.226 * * *$ & 0.044 & -0.117 & 0.080 & 0.049 & 0.055 & $0.317 * * *$ & 0.055 \\
\hline & & II & Coal & $-0.473^{* * *}$ & 0.074 & & & & & & \\
\hline & & os & Coal & $-0.692^{* * *}$ & 0.013 & & & & & & \\
\hline & & 至 & CCGT & $-0.815^{* * *}$ & 0.075 & & & & & & \\
\hline & & & OCGT & $-0.734 * * *$ & 0.019 & & & & & & \\
\hline \multirow{5}{*}{\multicolumn{3}{|c|}{ 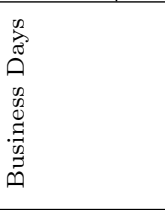 }} & Mo & $0.092 * * *$ & 0.011 & & & & & & \\
\hline & & & $\mathrm{Tu}$ & $0.093^{* * *}$ & 0.011 & & & & & & \\
\hline & & & We & $0.095^{* * *}$ & 0.011 & & & & & & \\
\hline & & & Th & $0.084 * * *$ & 0.011 & & & & & & \\
\hline & & & Fr & $0.066 * * *$ & 0.011 & & & & & & \\
\hline \multirow{3}{*}{ 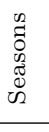 } & & & Spring & $-0.039 * * *$ & 0.010 & & & & & & \\
\hline & & & Summer & -0.011 & 0.009 & & & & & & \\
\hline & & & Autumn & $0.083 * * *$ & 0.009 & & & & & & \\
\hline
\end{tabular}

Notes: A markup is measured as a price bid minus approximated marginal cost. The last three columns contain coefficient estimates for interaction terms with regime dummy variables. ${ }^{*},{ }^{* *}$, and ${ }^{* * *}$ stand for the $10 \%, 5 \%$, and $1 \%$ significance levels, respectively. Adj. $\mathrm{R}^{2}=0.749$ and Obs. $=17,546$. 
Table D.2: Estimation Results Based on the Second Highest-Demand Trading Period

\begin{tabular}{|c|c|c|c|c|c|c|c|c|c|c|c|}
\hline \multicolumn{6}{|c|}{ Dependent Variable: log(Markup) } & \multicolumn{2}{|c|}{ Pre-Regime 4} & \multicolumn{2}{|c|}{ Regime 4} & \multicolumn{2}{|c|}{ Regime 5} \\
\hline \multicolumn{4}{|c|}{ Variable } & Coef. & Std. Err. & Coef. & Std. Err. & Coef. & Std. Err. & Coef. & Std. Err. \\
\hline \multirow{6}{*}{\multicolumn{3}{|c|}{ 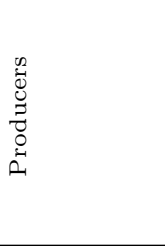 }} & NP & $3.421 *$ & 2.071 & $-15.353 * * *$ & 2.961 & $-8.185 * * *$ & 2.093 & 1.119 & 2.076 \\
\hline & & & PG & -0.552 & 1.317 & $8.937 * * *$ & 1.738 & 1.300 & 1.353 & 1.169 & 1.388 \\
\hline & & & TXU & $3.177^{* * *}$ & 0.269 & & & & & $0.036 * *$ & 0.017 \\
\hline & & & Ed & $1.873^{* * *}$ & 0.192 & 0.630 & 0.386 & 0.065 & 0.271 & $-1.466 * * *$ & 0.254 \\
\hline & & & $\mathrm{BE}$ & 2.697 & 1.891 & & & & & & \\
\hline & & & AES & $5.982 * * *$ & 0.064 & & & & & $0.872 * * *$ & 0.045 \\
\hline \multirow{6}{*}{$\begin{array}{l}\tilde{0} \\
.0 \\
0 \\
0 \\
0 \\
0 \\
0 \\
0 \\
0 \\
0 \\
0\end{array}$} & \multirow{6}{*}{\multicolumn{2}{|c|}{ 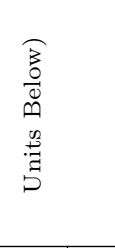 }} & NP & 0.190 & 0.192 & $1.336 * * *$ & 0.292 & $0.583 * * *$ & 0.194 & -0.063 & 0.193 \\
\hline & & & PG & $0.174 *$ & 0.105 & -0.054 & 0.133 & $0.268 * *$ & 0.111 & 0.084 & 0.109 \\
\hline & & & TXU & 0.018 & 0.014 & & & & & & \\
\hline & & & Ed & $0.031 * * *$ & 0.003 & $-0.036 * * *$ & 0.004 & -0.004 & 0.003 & $-0.023 * *$ & 0.010 \\
\hline & & & $\mathrm{BE}$ & 0.294 & 0.226 & & & & & & \\
\hline & & & AES & $-0.038 * * *$ & 0.003 & & & & & & \\
\hline \multirow{17}{*}{ 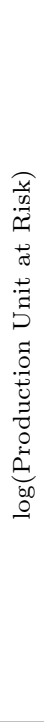 } & & & Coal & $-0.512 * * *$ & 0.123 & $0.784 * * *$ & 0.154 & $0.708^{* * *}$ & 0.131 & 0.040 & 0.130 \\
\hline & & B & Oil & $-0.366 * * *$ & 0.109 & $0.754^{* * *}$ & 0.135 & $0.663^{* * *}$ & 0.116 & 0.040 & 0.116 \\
\hline & & & CCGT & $0.299 * * *$ & 0.075 & & & & & & \\
\hline & & & OCGT & -0.162 & 0.173 & $0.936 * * *$ & 0.216 & $0.837 * * *$ & 0.185 & -0.173 & 0.189 \\
\hline & & & Coal & $0.271 * *$ & 0.134 & $-1.556 * * *$ & 0.185 & $-0.561 * * *$ & 0.135 & -0.238 & 0.149 \\
\hline & & Q & Oil & $0.377^{* * *}$ & 0.117 & $-1.312 * * *$ & 0.162 & $-0.525 * * *$ & 0.117 & -0.201 & 0.132 \\
\hline & & & OCGT & $1.025 * * *$ & 0.194 & $-2.451 * * *$ & 0.268 & $-1.068 * * *$ & 0.195 & $-0.548 * *$ & 0.220 \\
\hline & & $b$ & Coal & $-0.182 * * *$ & 0.044 & & & & & & \\
\hline & & E & CCGT & -0.013 & 0.063 & & & & & & \\
\hline & & & OCGT & $0.237 * *$ & 0.093 & & & & & & \\
\hline & & & Coal & $0.421 * * *$ & 0.029 & & & & & & \\
\hline & & I I & OCGT & $1.910 * * *$ & 0.074 & & & & & & \\
\hline & & & PSB & $0.226 * * *$ & 0.040 & -0.090 & 0.080 & 0.028 & 0.056 & $0.332 * * *$ & 0.051 \\
\hline & & II & Coal & $-0.438 * * *$ & 0.073 & & & & & & \\
\hline & & is & Coal & $-0.696 * * *$ & 0.011 & & & & & & \\
\hline & & 至 & CCGT & $-0.697 * * *$ & 0.014 & & & & & & \\
\hline & & & OCGT & $-0.733 * * *$ & 0.015 & & & & & & \\
\hline \multirow{5}{*}{ 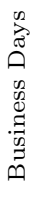 } & & & Mo & $0.087^{* * *}$ & 0.011 & & & & & & \\
\hline & & & $\mathrm{Tu}$ & $0.086 * * *$ & 0.011 & & & & & & \\
\hline & & & We & $0.082^{* * *}$ & 0.011 & & & & & & \\
\hline & & & Th & $0.069 * * *$ & 0.011 & & & & & & \\
\hline & & & Fr & $0.060 * * *$ & 0.011 & & & & & & \\
\hline \multirow{3}{*}{ 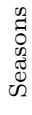 } & & & Spring & $0.022 * *$ & 0.010 & & & & & & \\
\hline & & & Summer & $-0.024 * * *$ & 0.009 & & & & & & \\
\hline & & & Autumn & $0.024 * * *$ & 0.009 & & & & & & \\
\hline
\end{tabular}

Notes: A markup is measured as a price bid minus approximated marginal cost. The last three columns contain coefficient estimates for interaction terms with regime dummy variables. ${ }^{*},{ }^{* *}$, and ${ }^{* * *}$ stand for the $10 \%, 5 \%$, and $1 \%$ significance levels, respectively. Adj. $\mathrm{R}^{2}=0.754$ and Obs. $=17,663$. 
Table D.3: Estimation Results Based on the Second Highest-Demand Trading Period

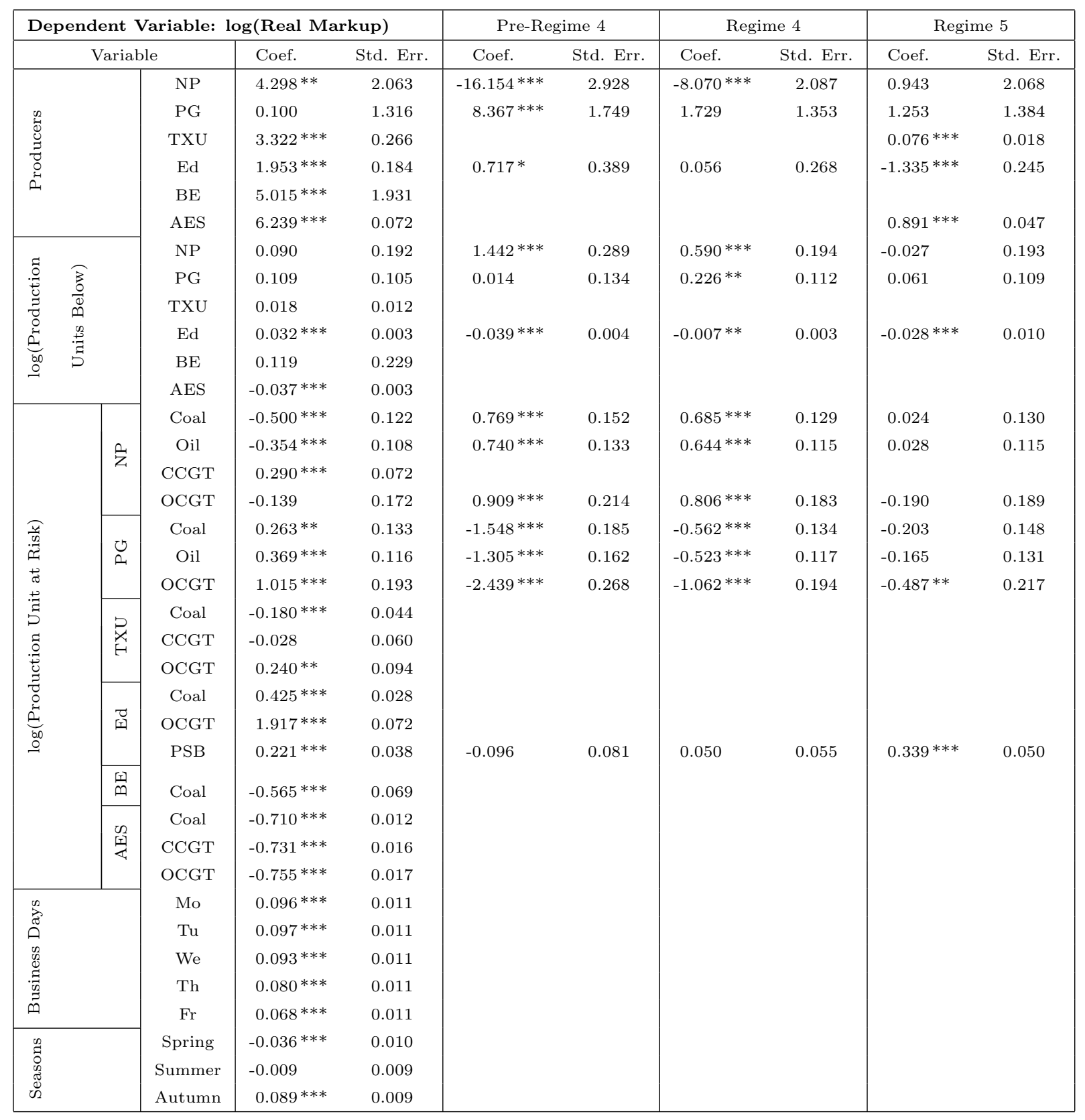

Notes: A markup is measured as a price bid minus approximated marginal cost. The last three columns contain coefficient estimates for interaction terms with regime dummy variables. ${ }^{*},{ }^{* *}$, and ${ }^{* * *}$ stand for the $10 \%, 5 \%$, and $1 \%$ significance levels, respectively. Adj. $\mathrm{R}^{2}=0.752$ and Obs. $=17,663$. 
Table D.4: Estimation Results Based on the Third Highest-Demand Trading Period

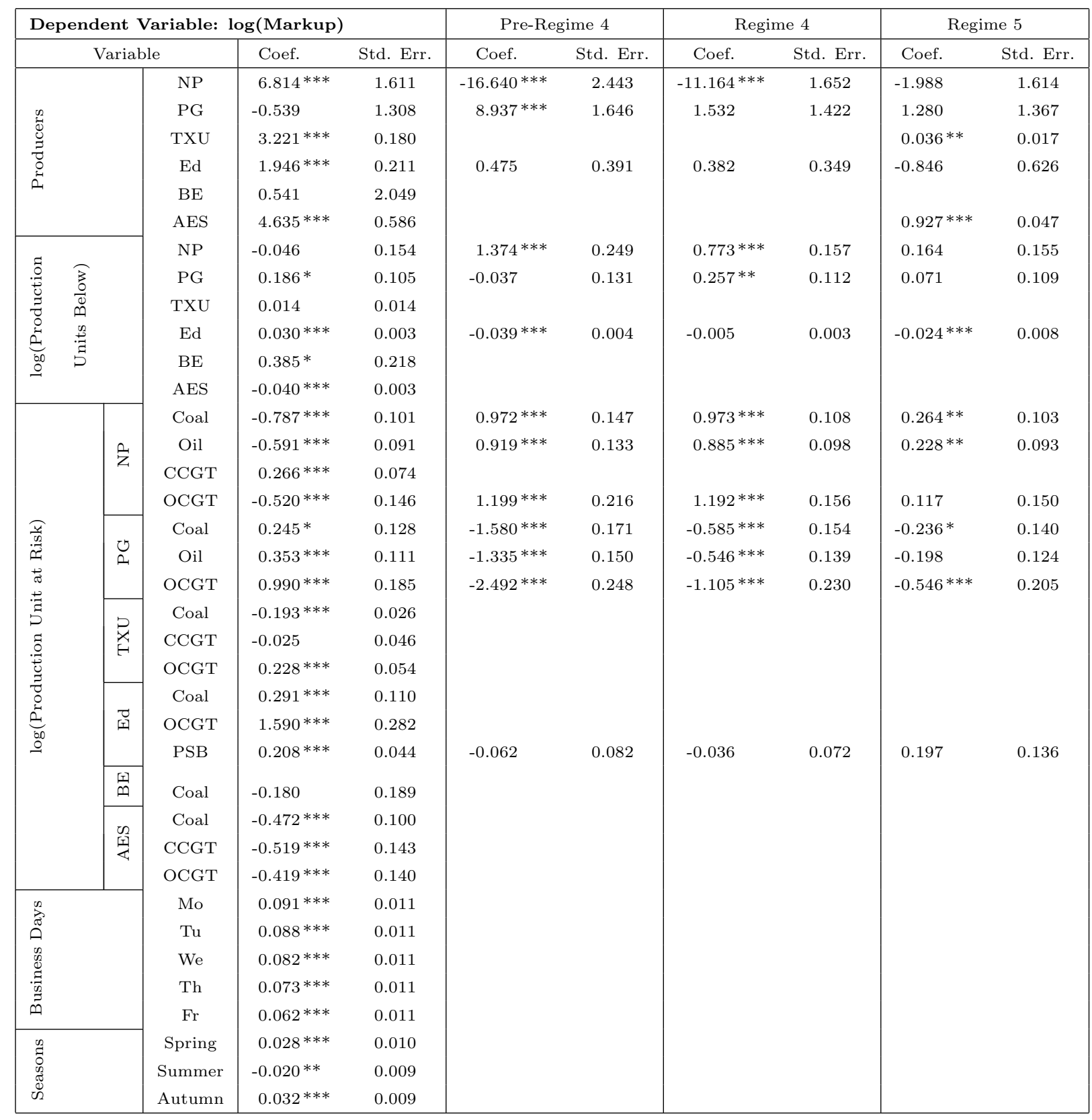

Notes: A markup is measured as a price bid minus approximated marginal cost. The last three columns contain coefficient estimates for interaction terms with regime dummy variables. ${ }^{*},{ }^{* *}$, and ${ }^{* * *}$ stand for the $10 \%, 5 \%$, and $1 \%$ significance levels, respectively. Adj. $\mathrm{R}^{2}=0.758$ and Obs. $=17,793$. 
Table D.5: Estimation Results Based on the Third Highest-Demand Trading Period

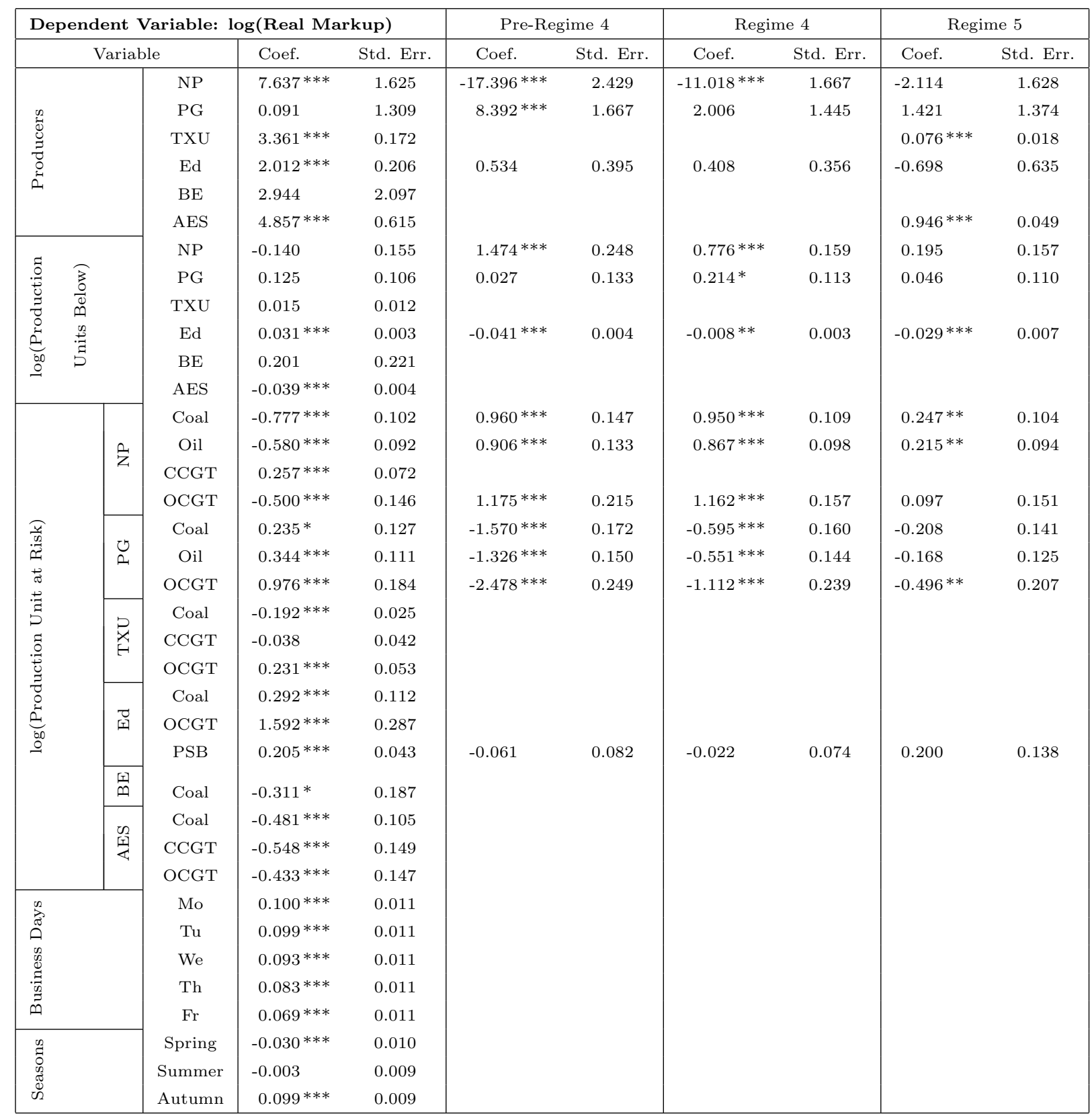

Notes: A markup is measured as a price bid minus approximated marginal cost. The last three columns contain coefficient estimates for interaction terms with regime dummy variables. ${ }^{*},{ }^{* *}$, and ${ }^{* * *}$ stand for the $10 \%, 5 \%$, and $1 \%$ significance levels, respectively. Adj. $\mathrm{R}^{2}=0.755$ and Obs. $=17,793$. 
Table D.6: Estimation Results Based on the Fourth Highest-Demand Trading Period

\begin{tabular}{|c|c|c|c|c|c|c|c|c|c|c|}
\hline \multicolumn{5}{|c|}{ Dependent Variable: log(Markup) } & \multicolumn{2}{|c|}{ Pre-Regime 4} & \multicolumn{2}{|c|}{ Regime 4} & \multicolumn{2}{|c|}{ Regime 5} \\
\hline \multicolumn{3}{|c|}{ Variable } & Coef. & Std. Err. & Coef. & Std. Err. & Coef. & Std. Err. & Coef. & Std. Err \\
\hline \multirow{6}{*}{\multicolumn{2}{|c|}{$\begin{array}{l}n \\
0 \\
0 \\
0 \\
0 \\
0 \\
0 \\
0\end{array}$}} & $\mathrm{NP}$ & $5.370^{* * *}$ & 1.685 & $-17.187^{* * *}$ & 2.745 & $-8.719 * * *$ & 1.791 & -0.612 & 1.687 \\
\hline & & $\mathrm{PG}$ & -0.056 & 1.358 & $7.396^{* * *}$ & 2.262 & 1.616 & 1.434 & 0.565 & 1.425 \\
\hline & & $\mathrm{TXU}$ & $3.378^{* * *}$ & 0.219 & & & & & $0.043^{* *}$ & 0.018 \\
\hline & & $\mathrm{Ed}$ & $2.027^{* * *}$ & 0.178 & 0.403 & 0.431 & $-0.533 *$ & 0.273 & $-1.622 * * *$ & 0.222 \\
\hline & & $\mathrm{BE}$ & 0.203 & 1.977 & & & & & & \\
\hline & & AES & $6.030^{* * *}$ & 0.065 & & & & & $0.915^{* * *}$ & 0.051 \\
\hline \multirow{6}{*}{ 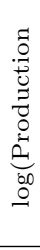 } & \multirow{6}{*}{ 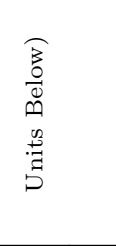 } & NP & -0.010 & 0.164 & $1.506^{* * *}$ & 0.260 & $0.704^{* * *}$ & 0.167 & 0.126 & 0.165 \\
\hline & & $P G$ & 0.166 & 0.107 & 0.031 & 0.168 & $0.236 * *$ & 0.113 & 0.105 & 0.111 \\
\hline & & $\mathrm{TXU}$ & 0.008 & 0.012 & & & & & & \\
\hline & & $\mathrm{Ed}$ & $0.028 * * *$ & 0.003 & $-0.035 * * *$ & 0.004 & 0.001 & 0.003 & $-0.031 * * *$ & 0.007 \\
\hline & & $\mathrm{BE}$ & $0.425^{* *}$ & 0.191 & & & & & & \\
\hline & & AES & $-0.042 * * *$ & 0.004 & & & & & & \\
\hline \multirow{17}{*}{ 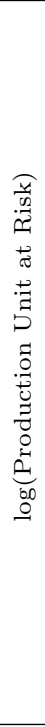 } & & Coal & $-0.588 * * *$ & 0.114 & $0.870^{* * *}$ & 0.178 & $0.630 * * *$ & 0.156 & 0.072 & 0.115 \\
\hline & & Oil & $-0.400 * * *$ & 0.103 & $0.810^{* * *}$ & 0.160 & $0.568^{* * *}$ & 0.142 & 0.049 & 0.105 \\
\hline & & $\mathrm{CCGT}$ & 0.127 & 0.128 & & & & & & \\
\hline & & OCGT & -0.209 & 0.165 & $1.020^{* * *}$ & 0.260 & $0.674^{* * *}$ & 0.230 & -0.171 & 0.169 \\
\hline & & Coal & 0.180 & 0.133 & $-1.389 * * *$ & 0.213 & $-0.568 * * *$ & 0.149 & -0.154 & 0.148 \\
\hline & & Oil & $0.299^{* * *}$ & 0.116 & $-1.171 * * *$ & 0.185 & $-0.531^{* * *}$ & 0.132 & -0.126 & 0.132 \\
\hline & & OCGT & $0.898^{* * *}$ & 0.193 & $-2.220 * * *$ & 0.306 & $-1.078^{* * *}$ & 0.220 & $-0.425 *$ & 0.218 \\
\hline & & Coal & $-0.224 * * *$ & 0.036 & & & & & & \\
\hline & & CCGT & -0.063 & 0.049 & & & & & & \\
\hline & & OCGT & $0.181^{* *}$ & 0.076 & & & & & & \\
\hline & & Coal & $0.423 * * *$ & 0.023 & & & & & & \\
\hline & & OCGT & $1.943^{* * *}$ & 0.058 & & & & & & \\
\hline & & PSB & $0.186^{* * *}$ & 0.037 & -0.042 & 0.089 & $0.154^{* * *}$ & 0.057 & $0.377^{* * *}$ & 0.046 \\
\hline & & Coal & -0.180 & 0.216 & & & & & & \\
\hline & & Coal & $-0.713 * * *$ & 0.011 & & & & & & \\
\hline & & CCGT & $-0.814 * * *$ & 0.072 & & & & & & \\
\hline & & OCGT & $-0.754 * * *$ & 0.015 & & & & & & \\
\hline \multirow{5}{*}{\multicolumn{2}{|c|}{ 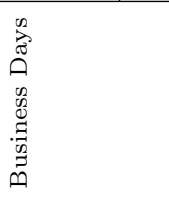 }} & Mo & $0.089^{* * *}$ & 0.011 & & & & & & \\
\hline & & Tu & $0.085^{* * *}$ & 0.011 & & & & & & \\
\hline & & We & $0.089 * * *$ & 0.011 & & & & & & \\
\hline & & Th & $0.071^{* * *}$ & 0.011 & & & & & & \\
\hline & & Fr & $0.063^{* * *}$ & 0.011 & & & & & & \\
\hline \multirow{3}{*}{ 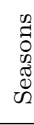 } & & Spring & $0.035^{* * *}$ & 0.010 & & & & & & \\
\hline & & Summer & -0.011 & 0.009 & & & & & & \\
\hline & & Autumn & $0.040^{* * *}$ & 0.009 & & & & & & \\
\hline
\end{tabular}

Notes: A markup is measured as a price bid minus approximated marginal cost. The last three columns contain coefficient estimates for interaction terms with regime dummy variables. ${ }^{*},{ }^{* *}$, and ${ }^{* * *}$ stand for the $10 \%, 5 \%$, and $1 \%$ significance levels, respectively. Adj. $\mathrm{R}^{2}=0.760$ and Obs. $=17,913$. 
Table D.7: Estimation Results Based on the Fourth Highest-Demand Trading Period

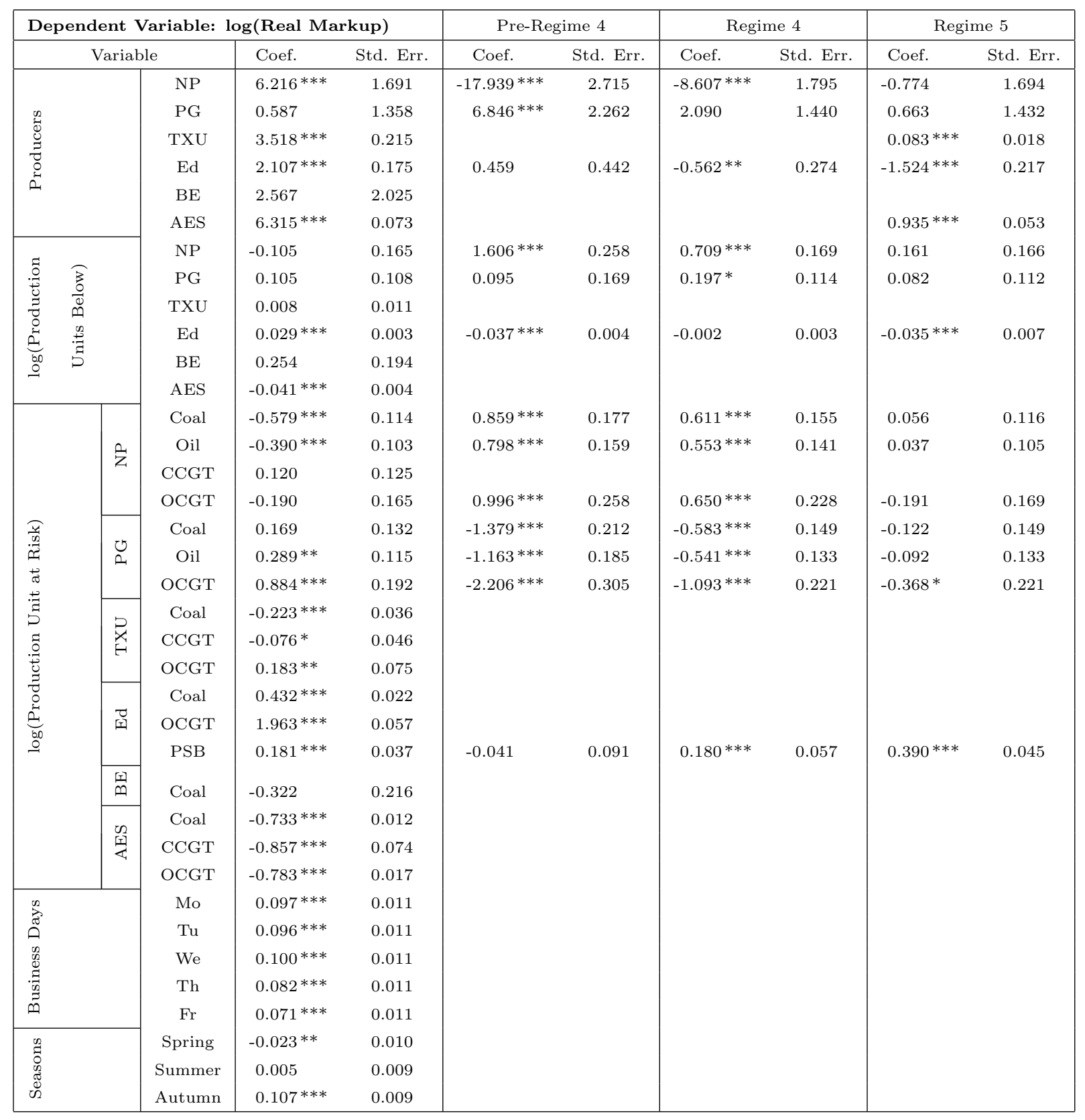

Notes: A markup is measured as a price bid minus approximated marginal cost. The last three columns contain coefficient estimates for interaction terms with regime dummy variables. ${ }^{*},{ }^{* *}$, and ${ }^{* * *}$ stand for the $10 \%, 5 \%$, and $1 \%$ significance levels, respectively. Adj. $\mathrm{R}^{2}=0.758$ and Obs. $=17,913$. 
Table D.8: Estimation Results Based on the Fifth Highest-Demand Trading Period

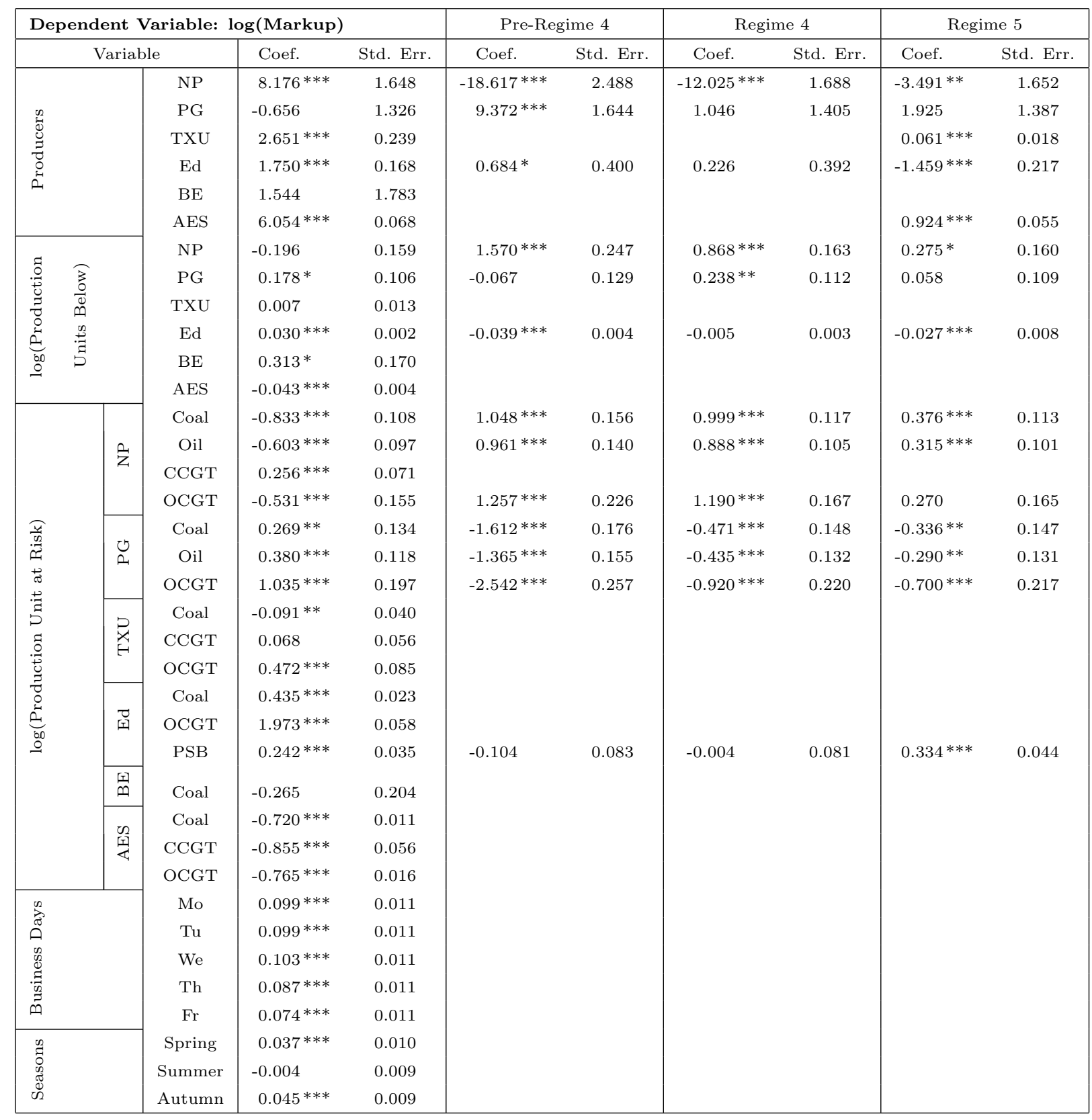

Notes: A markup is measured as a price bid minus approximated marginal cost. The last three columns contain coefficient estimates for interaction terms with regime dummy variables. ${ }^{*},{ }^{* *}$, and ${ }^{* * *}$ stand for the $10 \%, 5 \%$, and $1 \%$ significance levels, respectively. Adj. $\mathrm{R}^{2}=0.765$ and Obs. $=17,983$. 
Table D.9: Estimation Results Based on the Fifth Highest-Demand Trading Period

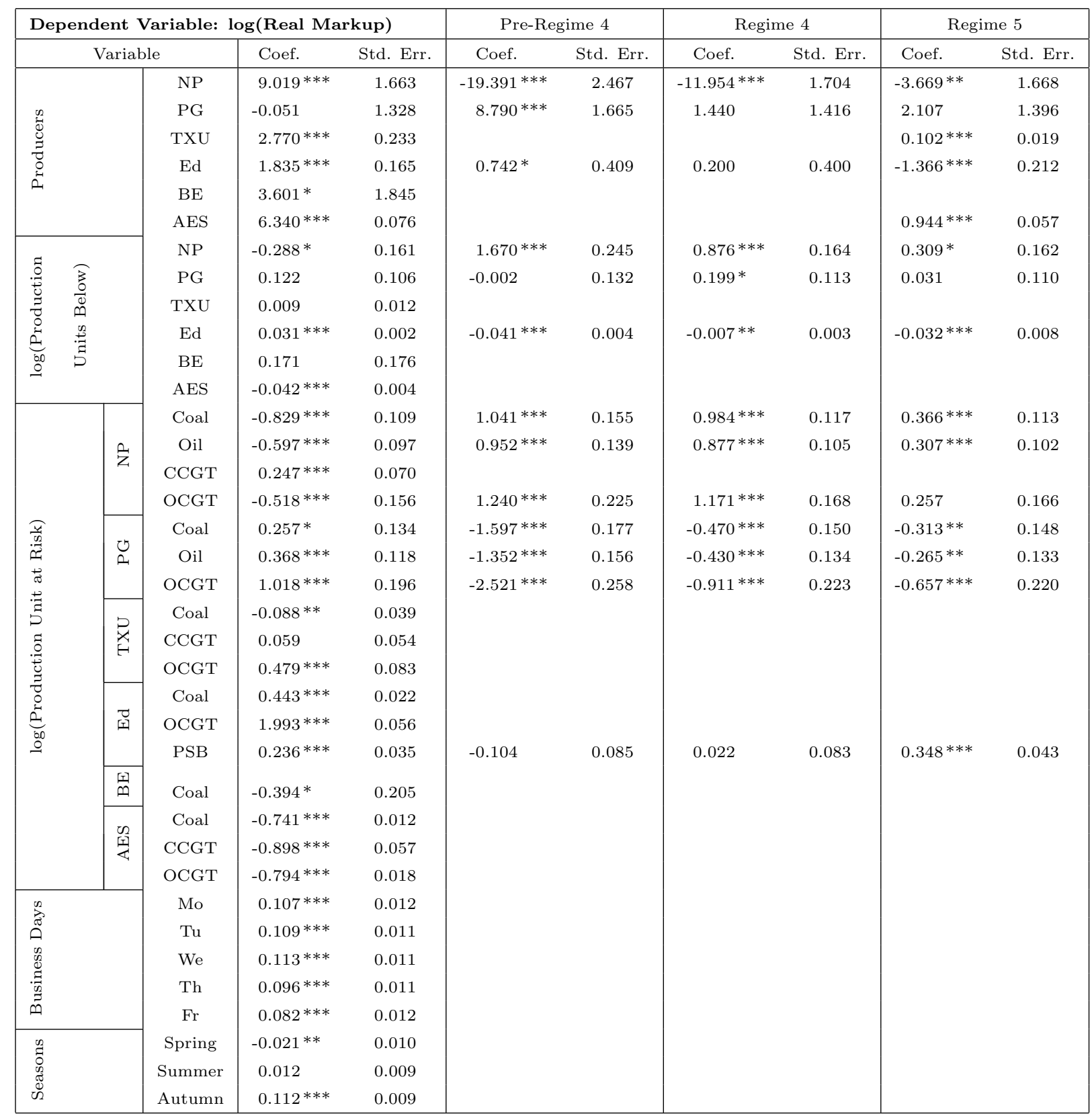

Notes: A markup is measured as a price bid minus approximated marginal cost. The last three columns contain coefficient estimates for interaction terms with regime dummy variables. ${ }^{*},{ }^{* *}$, and ${ }^{* * *}$ stand for the $10 \%, 5 \%$, and $1 \%$ significance levels, respectively. Adj. $\mathrm{R}^{2}=0.763$ and Obs. $=17,983$. 


\section{E Abbreviations}

$\begin{array}{ll}\text { BE } & \text { British Energy } \\ \text { CC } & \text { Competition Commission (formerly MMC) } \\ \text { CCGT } & \text { Combined Cycle Gas Turbine } \\ \text { CEGB } & \text { Central Electricity Generation Board } \\ \text { CP } & \text { Capacity Payment } \\ \text { DGES } & \text { Director General of Electricity Supply } \\ \text { Ed } & \text { Edison } \\ \text { ESI } & \text { Electricity Supply Industry } \\ \text { IPP } & \text { Independent Power Producer } \\ \text { LOLP } & \text { Loss of Load Probability } \\ \text { MMC } & \text { Monopolies and Mergers Commission } \\ \text { NETA } & \text { New Electricity Trading Arrangements } \\ \text { NGC } & \text { National Grid Company } \\ \text { NP } & \text { National Power } \\ \text { OCGT } & \text { Open Cycle Gas Turbine } \\ \text { OFFER } & \text { Office of Electricity Regulation } \\ \text { PB } & \text { Price Bid } \\ \text { PG } & \text { PowerGen } \\ \text { PPP } & \text { Pool Purchase Price } \\ \text { PSB } & \text { Pumped Storage Business } \\ \text { PSP } & \text { Pool Selling Price } \\ \text { REC } & \text { Regional Electricity Company } \\ \text { SFE } & \text { Supply Function Equilibrium } \\ \text { SMP } & \text { Value of Lost Load } \\ \text { VLL } & \end{array}$




\section{Working Paper Series}

ISSN 1211-3298

Registration No. (Ministry of Culture): E 19443

Individual researchers, as well as the on-line and printed versions of the CERGE-EI Working Papers (including their dissemination) were supported from the European Structural Fund (within the Operational Programme Prague Adaptability), the budget of the City of Prague, the Czech Republic's state budget and the following institutional grants:

- Center of Advanced Political Economy Research [Centrum pro pokročilá politickoekonomická studia], No. LC542, (2005-2010);

- Economic Aspects of EU and EMU Entry [Ekonomické aspekty vstupu do Evropské unie a Evropské měnové unie], No. AVOZ70850503, (2005-2010);

- Economic Impact of European Integration on the Czech Republic [Ekonomické dopady evropské integrace na ČR], No. MSM0021620846, (2005-2011);

Specific research support and/or other grants the researchers/publications benefited from are acknowledged at the beginning of the Paper.

(c) Sherzod N. Tashpulatov, 2010

All rights reserved. No part of this publication may be reproduced, stored in a retrieval system or transmitted in any form or by any means, electronic, mechanical or photocopying, recording, or otherwise without the prior permission of the publisher.

Published by

Charles University in Prague, Center for Economic Research and Graduate Education (CERGE) and

Economics Institute ASCR, v. v. i. (EI)

CERGE-El, Politických vězňů 7, 11121 Prague 1, tel.: +420 224005 153, Czech Republic.

Printed by CERGE-EI, Prague

Subscription: CERGE-EI homepage: http://www.cerge-ei.cz

Phone: + 420224005153

Email: office@cerge-ei.cz

Web: http://www.cerge-ei.cz

Editor: Michal Kejak

Editorial board: Jan Kmenta, Randall Filer, Petr Zemčík

The paper is available online at http://www.cerge-ei.cz/publications/working_papers/.

ISBN 978-80-7343-213-3 (Univerzita Karlova. Centrum pro ekonomický výzkum a doktorské studium)

ISBN 978-80-7344-203-3 (Národohospodářský ústav AV ČR, v. v. i.) 
CERGE-EI

P.O.BOX 882

Politických vězňů 7

11121 Praha 1

Czech Republic http://www.cerge-ei.cz 